\title{
"Com o Pé sobre um Vulcão": Africanos M inas, I dentidades e a Repressão Antiafricana no Rio de Janeiro (1830-1840)
}

\author{
Carlos Eugênio Líbano Soares e Flávio G omes
}

Resumo

Este artigo busca retratar o terror que assomou os moradores brancos da cidade do Rio de J aneiro quando do êxodo crescente de africanos ocidentais da cidade de Sal vador, na Bahia, para o Rio de J aneiro, principalmente após a derrota do levante malê de 1835. D iscute também a questão das identidades políticas construídas pelos africanos ocidentais ocultas sob o manto de identidades "étnicas", geral mente muito mal discutidas pelos historiadores. Também debate o medo da "politização" do protesto escravo que assolou os senhores do Rio nos anos 1830, dentro do quadro maior de inconformismo com os políticos conservadores na R egência.

Palavras-chave: africanos minas; levante malê; identidade étnica; identidade política. 
CarlosEugênio Líbano Soareseflávio G omes

\begin{abstract}
"O ne F oot on a Volcano": M inas Africans, I dentities and

Anti-African Repression in Rio de Janeiro (1830-1840)
\end{abstract}

This article endeavors to describe the terror that engulfed the white inhabitants of the city of Rio de Janeiro at the time of the growing exodus of W est Africans from the city of Salvador, state of Bahia, in a moveto $R$ io de J aneiro, especially after the defeat of the $M$ alêuprising in 1835. It al so discusses the question of political identities constructed by W est Africans, concealed behind a screen of "ethnic" identities, generally very badly handled by historians. Furthermore, it discusses the fear of "polarization" of the slave protest that wasfelt by slave owners of R io in the eighteen thirties, within the larger picture of inconformity with the conservative policies enacted in the Regency.

Keywords: M inas Africans; M alê uprising; ethnic identity; political identity; N egroes.

Résumé

"Les Pieds sur un Volcan": Africanos M inas, I dentités et Répression Antiafricaine à Rio de Janeiro (1830-1840)

$D$ ans cet article, on cherche à rendre compte de la terreur qui s'empara des Blancs résidant à Rio de Janeiro lors de l'exode massif d'Africains occidentaux venant de la ville de Salvador, à Bahia, surtout après I'échec du soulèvement malê de 1835. Par ailleurs, on y discute la question des identités politiques construites par les Africains occidentaux dissimulées sous le couvert d'identités "ethniques", en général très peu discutées par les historiens. 0 n y examine aussi la peur de la "politisation" des revendications des esclaves chez les propriétaires de Rio pendant les années 1830, dans le cadre plus large de I'insatisfaction envers les politiciens conservateurs de la Régence.

M ots-clé: africanosminas; soulèvement malê; identitéethnique; identité politique; N oirs.

Estudos Afro-Asiáticos, Ano 23, ํㅡ 2, 2001, p. 2 
E studos contemporâneos têm procurado entender a formação/transformação dasidentidades escravas, africanas e crioulas nas experiências da escravidão no Brasil. Para além das abordagens que transformavam africanos e seus descendentes em "coisas", destituídos de esperanças e recordações, transformados em números do tráfico e totalmente passivos diante das supostas lógicas inexoráveis de um sistema social, surgem pesquisas quetentam conectar as vivências escravas - contextos urbanos e rurais apresentam diferenças - não só com as sociedades africanas, via de regra romantizadas, maisfundamental mente com contextos atlânticos (até transatlânticos) de reinvenções e reinterpretações culturais. É bom destacar que - aindaque por outros percursos - tem ocorrido uma retomada de um debateintelectual com longa trajetória. N o Brasil, excetuando alguns estudos clássicos, ${ }^{1}$ pode-sedizer que tem havido uma "redescoberta" da África, para pensar os escravos ea escravidão. ${ }^{2}$ Esforço esteque pouco tem avançado para pensar os anos imediatamente pós-emancipação.

$N$ ão necessariamente a escravidão, mas o negro apareceu como foco de estudo no Brasil na virada do século XIX para o XX, associado ao Folcloreeaos temas da diversidade cultural brasileira. Falava-se em reminiscência da cultura africana no Brasil. Era necessário classificá-la e também escolher seus cenários. A África no Brasil teria pal cos privilegiados. Estes a guardariam nos seusmisté rios e encantos. Foi um pouco por aí que uma certa antropologia caminhou numa tradição que - guardada as especificidades percorreu de $\mathrm{N}$ ina Rodrigues, a Arthur Ramos, Edison Carneiro, Roger Bastide e Pierre Verger. $M$ ais recentemente foram demonstrados os caminhos da "invenção" africana no Brasil. H avia mesmo, parodiando Góis D antas, usos e abusos da África no Brasil (cf. $D$ antas, 1988). Tradições, não necessariamente inexistentes, mas também inventadas ou redefinidas. Textos de $\mathrm{M}$ anuela $\mathrm{C}$ arneiro, J oão R eis, R enato da Silveira, da própria Beatriz Góis D antas, Robert Slenes, Peter Fry e outros já destacaram isto. ${ }^{3}$ C ontudo este debate - ainda bem - está longe de ganhar um ponto final. Isto

Estudos Afro-Asiáticos, Ano 23, ํㅡ2, 2001, p. 3 
não só para o B rasil. Aqui ou acolá, abordagens - algumas permeadas não só por uma suposta el oqüência acadêmica - reaparecem. $G$ anham novas formas e outros argumentos. Ênfases e caminhos diversos.

M as seaÁfricano Brasil podia ter um lugar idealizado, a "resistência" escrava, aquel a fundamental mente com um sentido cultural, tinha como espaço privilegiado o quilombo. 0 outro local da "resistência" seria o campo da religião. Esta foi a construção de H istórias eAntropologia da escravidão no Brasil atéo início do último quartel do século XX.

Articulando religiosidade, cultura e "resistência" - tendo como pano de fundo o protesto escravo - um tipo de abordagem foi preponderante. Surgiu nos anos 30, sob a influência de N ina Rodrigues e outros escritos temáticos da chamada Antropologia Cultural. A partir deste pressuposto antropológico tinha-se o objetivo de caracterizar a resistência escrava no Brasil numa perspectiva da "contra-aculturação". Sabemos que foram nas obras de Arthur Ramos, Edison C arneiro e, mais tarde, Roger Bastide, que tiveram força interpretações em torno da idéia de "resistência cultural". O s significados religiosos das culturas escravas seriam tãosomente recriações genuínas de uma cultura de pureza africana.

U m dos principais problemas deste tipo de análise foi a conceituação de "cultura". Em grandemedida, esta foi vista como uma experiência social "estática" ou com mudanças históricas lineares, primordialmente pela idéia de difusão. As culturas africanas do "negro" foram assinaladas como parte deum mundo "natural", em que genuíno e "raiz" eram as palavras-chave (ver Bastide, 1974, 1985; Carneiro, 1964, 1966; Ramos, 1942, 1979, 1935, 1953; Rodrigues, 1900).

Estudos mais recentes, pautados pela $\mathrm{H}$ istória Etnográfica, têm demonstrado como as comunidades escravas nas Américasfundamentalmente forjaram uma interação e transformação cultural original ediversificada. I sto mesmo num mundo de muita opressão e violência. C ritica-se, assim, a argumentação, por exemplo, de que havia uma forte separação entre a construção de identidade dos escravos crioulos nas plantações e o caráter "africano" das comunidades de fugitivos (quilombos/mocambos), provocando com isso um grande distanciamento cultural entre negros nascidos na terra e aqueles no além Atlântico. H avia o caráter da interação e o desenvolvimento de novas sínteses na constituição das culturas escravas. Esse processo possivelmente pode ter provocado mudanças significativas em al gumas comunidades. Argumentamos no mesmo senti-

Estudos Afro-Asiáticos, Ano 23, № 2, 2001, p. 4 
do deterem sido criados conteúdos esignificados culturais originais tanto nas senzalas como nos quilombos; nas áreas rurais, expostas ou não ao maior impacto do tráfico negreiro; ou aquelas que vivenciaram experiências singulares de tráfico interno; em contextos urbanizados, com grande concentração de africanos, reconfigurações étnicas edesociabilidades. Paratais processos - invisíveis, opacose multifacetados - melhor seria falar, sempre, de recriações e reinven ções. Para além das dispersas evidências - e a necessidade permanente de se remover o pó da documentação disponível depositada nos arquivos - tomamos como base um amplo debate teórico e metodológico sobre as especificidades das culturas escravas nas Américas. $\mathrm{N}$ ão haveria necessariamente (enquanto model os cristalizadosefuncionalistas) umacultura "branca" e, outra "negra", uma européia ou africana nas Américas, e estas aqui teriam encontrado uma também única e verdadeira cultura indígena. Pelo contrário, houve pluralidades culturais - com semel hanças, diferenças, aproximações e distanciamentos - de várias origens que se engendraram, gestando experiências culturais diversas. Cultura, portanto, deve ser lida (e/ou procurada) no contexto das experiências históricas de seus agentes.

Significados culturais de origens africanas eram reinventados pel os escravos no Brasil, não só para a primei ra geração de africanos aqui desembarcados, mas também as seguintes, de cativos crioulos. Podemos pensar as culturas escravas, não numa perspectiva essencialista de "africanismos" - ou mesmo como se os quilombos fossem necessariamente ou exclusivamente lugares ou guardiães de uma "cultura africana". É possível entender a cultura quilombola (ou culturas quilombolas para marcar suas complexidades e diversidades) também como uma extensão da cultura escrava. Senzal as e choupanas podiam ser fontes constantes debackgrounds culturais para os habitantes dos quilombos, como estes para as mesmas. É claro que em al gumas situações, os impactos demográficos do tráfico negreiro, a crioulização das populações escravas em geral eo isolamento forçado de al guns grupos de fugitivos podem ter provocado interações culturais diferentes. ${ }^{4} 0$ fato é que africanos e crioulos - e aqui já há uma generalização - não estavam completamente afastados nas ruas, nas senzal as e nos quilombos de outros setores escravos, livres e negros.

Este artigo tem como objetivo, considerando um contexto deforte repressão antiafricana, pensar a gestação deidentidades de africanos, escravos, libertos e crioulos, especialmente nas áreas urbanas do Rio de Janeiro. ${ }^{5}$ Partimos inicialmente de críticas aos

Estudos Afro-Asiáticos, Ano 23, ำ 2, 2001, p. 5 
pressupostos, que isolam significados de "cultura" e "resistência" para pensar as experiências da escravidão eliberdade. Aquelas dos africanos minas - com a "cor do mêdo" - queassolou a C ortena década de 1830 são exemplos preciosos para refletir sobre movimentos identitários, refundindo (etambém transformando) concepções de "nações" e "etnicidade".

Temores e M alês

Em fins de 1835, o presidente da Província do Rio de Janeiro, J oaquim J osé R odrigues Torres, oficiava ao M inistério daJ ustiça a respeito dos seguidos boatos e revelações de "projectos" de insurrei ções escravas na Corte e no interior. Tal vez, visando acalmar as autoridades imperiais, dizia que tais rumores eram exagerados, posto que frutos de denúncias que pareciam "nimiamente tintas com a côr do medo". "T intas com a cor do medo" eram com certeza as freqüentes denúncias que chegavam à C orte de vários pontos da Província fluminense e de outras partes do Império. Esta expressão pode se constituir, para efeito de análise, numa metáfora igual mente revel adora. $\mathrm{N}$ as mentes daquel es que temiam as revoltas de escravos e suas conseqüências, o medo tinha, por certo, uma coloração, ainda que simbólica. Era negra, a mesma que a dos escravos, principalmente os de origem africana. $N$ esse sentido, a "cor do medo" podia ter vários significados.

Em meados da década de 1830, devido a repercussões da revolta dos malês na Bahia, em várias regiões brasileiras temeu-se uma insurreição geral dos escravos. $\mathrm{N}$ a ocasião, em meio a tantos rumores, denúncias e boatos, imagens do medo se ampliavam. As autoridades e a população em geral, cada vez mais aterrorizadas com a possibilidade real de eclodir um levante africano, não mencionavam somente os episódios ocorridos em Salvador em 1835. Renascia igualmente o fantasma haitiano. Em janeiro de 1836, uma denúncia anônima é enviada ao governo imperial, lembrando-Ihe o "exemplo da I lha de São D omingos". 0 denunciante, na ocasião, baseava-se em informações relativas ao achado, junto a um escravo, de "um papel queservia deplano paraensinar como os pretos saberão juntar no dia 24 e 25 para começar a matança dos brancose pardos". Em um tom alarmante, o anônimo pedia providências mais efetivas por parte das autoridades do I mpério, uma vez que acreditava quelogo a sociedade, em particular a C orte, seria vítima de uma "nuvem negra", representada por uma desordem

Estudos Afro-Asiáticos, Ano 23, № 2, 2001, p. 6 
de africanos. 0 medo ganhava mais significados simbólicos. Alguns possivelmente imaginavam uma grande tempestade quese abateria sobretodosos "brancos", uma vez que a "nuvem negra" se preparava para escurecer todo o céu. ${ }^{7}$

0 fantasma do haitianismo atacaria em outros lugares. Algumas denúncias diziam existir um "cafre" haitiano, chamado M oiro, que estava convidando os escravos das vilas do Bananal, Areias, Barra M ansa e São J oão M arcos, no Rio de Janeiro, para se insurgirem e quejá havia mesmo cerca de sete mil cativos envolvidos nesse plano. Fato interessante é que o dito haitiano foi preso e "não negou" as acusações de que estaria convidan do vários cativos para participar de uma insurreição, "porém disse, que estava brincando". B rincadeira ou não, o certo éque as autoridades provinciais pediram a expulsão deste haitiano do Brasil. ${ }^{8}$

0 medo, ao que parece, cruzava fronteiras e mares. 0 secretário do Foreign O ffice Bandenel, afirmaria, diante do Select Committee on the Slave Trade, que "uma insurreição muito séria deescravos havia acontecido na Bahia queassustou muito o governo, todo o governo do Brasil" (C unha, 1985:72). O M inistro da Justiça, já em março de 1835, solicitava às autoridades policiais da Corte providências "indispensáveis" para a "tranqüilidade dos habitantes da C apital", evitando "a reprodução das cenas da Bahia". A própria Assembléia Provincial do Rio de Janeiro enviou uma moção às principais autoridades do I mpério, denunciando a existência de "sociedades secretas" na C orte. N estas havia a participação e mesmo a contribuição financeira de escravose "Iivres de cor" para que "agitadores en carregados de propagar doutrinas subversivas", e disfarçados de vendedores ambulantes espalhassem-nas junto aos cativos nas áreas rurais (ibidem:74; Chalhoub, 1990:187).

O stemores em relação aos malês baianos eaos rebeldes haitianos misturavam-se agora para projetar um fantasma de um movimento internacionalista de sublevações escravas. Diversas autoridadestemiam aexistência de planos derevoltas articuladas entreescravos de várias partes das A méricas com a participação de abolicionistas ingleses e emissários internacionais. Ainda em 1835, o M inistro daJ ustiça recebeum ofício reservado do agente diplomático do Brasil em Londres, afirmando que: "noticias recentes do Sul dos EstadosU nidos" confirmavam haver "muitosindivíduos mandados por várias Sociedades de Philantropia e Emancipação" da Inglaterra com "o fim de promoverem a liberdade" dos escravos, "excitando a levantes, espal hando entre eles idéias de insubordinação". A repres-

Estudos Afro-Asiáticos, Ano 23, ำ 2, 2001, p. 7 
são teria sido imediata, posto que vários destes "emissários" foram "apanhados e enforcados imediatamente, outros ameaçados, emuitos negros, ou mortos ou rigorosamente castigados". Preocupado com o Brasil - certamente com as imagens do levante malê na mente - 0 tal agente diplomático sugeriu providências (inclusive com recursos para "despesas extraordinárias") taiscomo "introduzir em uma ou mais das Sociedades Philantropicas dal nglaterra, pessoa de confiança que pudesse dar conta de qualquer tentativa contra 0 sossego do Brasil que nelas se originasse". ${ }^{\prime}$

$\mathrm{N}$ a movimentada década de 1830 não era só a revolta malê que atormentava as autoridades do I mpério quanto a possíveis repercussões junto aos escravos. As rebeliões regionais, que pi pocavam desdeo Sul farroupilha atéo $\mathrm{N}$ orte cabano, ameaçavam a estabilidade da Regência, que ainda não completara quatro anos de turbulenta existência. Como que prenunciando tormentosos acontecimentos, apenas quatro dias depois de desencadear o protesto malê em Salvador (ainda desconhecido no Rio) foi preso um preto mina acusado de "curador defeitiços" ${ }^{10} \mathrm{~N}$ aquel e contexto, 0 medo dos africanos minas da Bahia foi mais um ingrediente perturbador para a já tensa situação entre as forças policiais e a massa escrava e popular no centro da Corte.

$\mathrm{N}$ a repressão desencadeada na capital do Império - e, por certo, em outras províncias ecidades, para al ém deSalvador - em 1835 e 1836, o foco principal foi, de fato, o perigo representado pelos africanos ocidentais, os minas, como eram genericamente denominados. ${ }^{11} \mathrm{Em}$ todos os boletins policiais da Corte - emesmo no interior da província fluminense - elesalcançam uma presença não vista antes. Segundo K arasch, no Rio deJ aneiro da primeira metade do século XIX, os africanos da Costa 0 cidental eram quase $7 \%$ da população escrava africana. Já H olloway demonstra, com os registros de prisões, que os africanos minas representavam $17 \%$ e $8,9 \%$, respectivamente, da população escrava africana e geral no Rio de Janeiro em $1850 .^{12}$

As repercussões do levantemalêde 1835 não intimidaram os minas no Rio de Janeiro. Pelo contrário, os estimularam ainda mais a se levantar contra a opressão dos escravistas. Em Santa Rita, o preto minaJ oséfoi condenado a doismeses de prisão por desobe decer a um oficial de ustiça e ter empregado a força contra o mesmo (AN RJ, IJ 6, 170, "Partes... 2.5.1835").

M as um dos maiores mistérios do ano de 1835 foram oschamados "Clubes de Africanos" na Corte. Ao que tudo indica, eram centros de reuniões de africanos libertos ou livres, que agora eram,

Estudos Afro-Asiáticos, Ano 23, № 2, 2001, p. 8 
mais do que tudo, razão principal da dor de cabeça das autoridades. Estes africanos podiam ser mascates livres vindos do outro lado do Atlântico (pombeiros), que coabitavam com africanos escravos e libertos em casas alugadas que serviam de centros de encontro. ${ }^{13}$

A intensidade do pânico na Corte podia aumentar com os assustadores boatos de revoltas escravas nas áreas rurais. Barra M ansa, Bananal, Resende, Areias, São J osé do Príncipe, foram alguns dos municípios nos quais rumores de levante colocaram a população em polvorosa. Para alívio dos governantes, quasetodosestes boatos eram mais fruto da paranóia da eliteescravista do quesinais de uma explosão próxima. M as a tensão no ar não diminuiu. Em Piraí, comarca de Barra M ansa, foram achadas, como sinais de uma revolução escrava próxima, bandeiras com os dizeres “Viva a Santa C ruz". D epois se reconheceu pertencerem a uma festa de coroação de rei negro. Em Areias foram presos cinqüenta negros suspeitos de sediciosos, e apreendidas bandei rolas e mais instrumentos. Em São J oão do Príncipe foram detidos mais de cem escravos. Em Resende chegou-se ao cúmulo deseprender três pretos queestavam em um jogo de cartas. Posteriormenteuma testemunha dos planos do levante confessou ao juiz de paz de Bananal que estava embriagado. ${ }^{14}$

A draconiana legislação repressiva de junho de 1835, ordenando a pena de morte para escravos acusados de matar seus senhores ou próximos, condenados em processos sumaríssimos, é logo colocada em prática no Rio, como remédio contra o medo endêmico do levante negro. M as faltava carrasco para a execução da pena máxima. 0 ChefedePolícia tenta, em vão, atécom promessa de comutação de pena, convencer os presos a tomar o lugar do algoz. M as a solidariedade do cárcere era mais forte. Aliás, mesmo dentro das cadeias o clima era de insurreição. 0 carcereiro da ilha de Santa Bárbara enviou um ofício ao Chefe de Polícia da Corte apontando a "insubordinação" dos presos, que se recusam aos trabalhos ordinários nas celas, como carregar água, os quais "nem os pretos cativos querem fazer". ${ }^{16}$

0 segundo semestre de 1835 continuou tormentoso para as autoridades. Além dos capoeiras, número significativo de escravos são presos por conduzirem armas, ou mesmo por desacato a autoridade. U ma simples comparação dos boletins mensais de prisão, de 1833 e 1834, demonstram a escalada insurreta. $M$ ais do que nunca, as ruas da C orte em 1835 são tomadas pela maioria africana e escrava na cidade. $\mathrm{N}$ em os símbolos visíveis da dominação,

Estudos Afro-Asiáticos, Ano 23, № 2, 2001, p. 9 
como os libambos de negros acorrentados, intimidam a avassaladora onda rebelde que percorre a cabeça dos pretos e pretas da cidade. 0 s proprietários brancosficam enclausurados em suascasas, com medo da onda negra nas ruas.

A vaga revolucionária que toma o Império, fazendo eclodir levantes de $\mathrm{N}$ ortea Sul do país, chega inevitavel menteà capital do Império, enão vem somenteda Bahia. FelipeM oçambique, ao ser levado para o C alabouço do C astelo para ser supliciado, fez amaldiçoar seus captores, pois "disseque havia de acontecer aqui o mesmo que aconteceu no Pará", onde a rebelião dos cabanos tomou o poder na capital da província (AN RJ, IJ 7, "Partes...12.11.1835"). A Corte não estava de modo nenhum isolada do contexto do Império. E o contexto do Império era também Atlântico.

Em alguns momentos - como Chalhoub bem definiu nas ruas da C orte, o medo ficaria sólido como uma rocha. Em juIho de 1835, um estranho ofício foi parar na mesa do temido chefe de polícia da C orte, Eusébio de Q ueiroz C outinho M atoso Câmara. Era sobre a apreensão, junto a africanos, de um papel escrito com "bizarros sinais", aparentando ser um alfabeto indecifrável. $\mathrm{N}$ inguém na repartição policial soubera decifrar tais escritos. Para decifrador foi convocado um africano nagô. 0 africano - não sem aparentar dificuldade - prontamente afirmou que aqueleera um alfabeto usado por um povo quevivia ao norte de sua terra original, naÁfrica 0 cidental, para onde osjovens defamílias proeminentes eram mandados, e que era usado pelos sábios de sua gente. Pausadamente ele traduziu o que parecia uma prece muçulmana, mas que reproduzia um diálogo entre defensores da paz eapologistas da "guerra". N ão pode haver dúvidas quea tal "guerra" na realidade era um sinônimo para rebelião. ${ }^{16}$

Ainda quecom significados bastanteenigmáticos (além da dificuldade ou então temor do próprio africano convocado para decifrar o texto), ${ }_{17}$ fica evidente - a partir da tradução - que o escrito servia como uma espécie de tal ismã para a guerra, eque o poder das palavras servia "como amuleto mágico para combatentes". ${ }^{18}$ Surgiam no final os "riscos" que, na verdade, eram as assinaturas em língua árabe. Afirmou o chefe de polícia que era um escrito religioso, defémuçulmana, mas queele vagamentepercebeu como deorigem "oriental". N o final, chegou-sea uma conclusão: o escrito pertencia a um "clube", ou grupo, que se reunia regularmente. Seguindo, porém, as opiniões do intérprete, Eusébio afirmaria que o talismã não era perigoso à ordem pública, mas apenas uma oração misteriosa, fruto das crendices supersticiosas do povo nagô.

Estudos Afro-Asáticos, Ano 23, ํo 2, 2001, p. 10 
0 poderoso Eusébio de Q ueiroz, com toda a sua sagacidade como C hefedePolícia, mesmo na quadra melindrosa quese estava atravessando em 1835, não percebeu o potencial oculto por trás daquelas misteriosas palavras, que aparentemente permaneceram enigmáticas - quem sabe justamente devido ao auxílio do intérprete nagô. Era sintoma de uma ameaça preocupante para a ordem escravista na Corte e outras partes do Império.

Estes misteriosos escritos testemunham a chegada, na Corte do Rio de Janeiro, de uma ameaça que já tinha estremecido corações e mentes na Província da Bahia - os mina-nagô, que havia muito pouco tempo tinham encabeçado o maisfugaz eviol ento levantejá ocorrido na cidade deSalvador, colocando em polvorosa a sua população e autoridades. A partir daí os africanos ocidentais - conhecidos como minas no Rio de Janeiro - vão realizar um verdadeiro êxodo da cidade de São Salvador para a capital do Império, movimento que vai transferir em definitivo para as ruas da C orte imperial o medo que assolava a capital baiana.

0 amuleto mina que caiu nas mãos do chefe de polícia pode sugerir um embate que se travava nos subterrâneos da complexa comunidade escrava, muitas vezes longe dos olhares e ouvidos dos vigilantes da ordem. U m embate que vai ter repercussões profundas nos caminhosfuturos do protesto escravo. U m embate entreos defensores da rebelião aberta, e aquel es que apontam outros caminhos. Por mais que tenhamos nas mãos apenas conjecturas, as palavras do escrito malê apontam claramente duas opções: o caminho da "guerra", que indica o levante, a insurreição, a rebelião generalizada - como tinha ocorrido havia pouco nas ruas de Salvador - e a alternativa talvez de resistência indireta, por meio da burla, da organização secreta, dafuga - epor quenão, dasedução.

A fraseinicial, como apontou o próprio Eusébio de Q ueiroz, indica que o papel era um talismã, de um tipo muito utilizado pelos malês muçulmanos da Bahia, como mostrado por João Reis, ${ }^{19}$ um amuleto para o combate, um protetor mágico das horas da refrega. A discussão encetada pelos personagens era profundamente política. Ela marcava os rumos futuros do movimento escravo mas que influenciavam livres, libertos e forros. Parece que ao final da prédica vence a proposta da "guerra", pois pelo menos ela é a mais defendida. M asnestemomento - princípios do ano de 1835 - o dilema ainda era forte.

A precipitação do levante de 25 de janeiro em Salvador teve graves repercussões. A repressão aos escravos eaos africanos em geral se agravava dia a dia. 0 cerco se fechava sobre as comunidades

Estudos Afro-Asiáticos, Ano 23, ํo 2, 2001, p. 11 
afro-muçulmanas dacidade, muitas das quaisinvisíveis. Asprisões se enchiam de suspeitos. 0 safricanos livres elibertos, queteoricamente gozavam de todos os direitos do resto da população livre, sentiam na carne o quanto o estigma da cor e da origem pesava sobre eles (cf. Flory, 1977; Abreu, 1999).

U ma onda de refugiados africanos rapidamente converge para fora da cidade deSalvador, eo destino demuitoséum só: acapital imperial, centro da maior comunidade africana urbana do país e do Continente. Em abril de 1835, a chegada de um brigue com 98 escravos da Bahia, detodas as origens, soou 0 alerta. 0 chefe de polícia impede o desembarque antes de uma profunda investigação. Emite ordens imediatas aos responsáveis pelo porto para quebarrassem a entrada detodos os escravos eprincipalmenteafricanos vindos da Bahia, atésegunda ordem. 0 medo da contaminação malêvarreu os pensamentos de Eusébio de Q uei roz logo após as primeiras notícias do levante na Bahia. M as elenão podia impedir 0 alastramento dos temores. ${ }^{20}$

Já havia africanos envolvidos diretamente na insurreição de janeiro em Salvador, transitando pelas ruas do Rio. Em maio, dois deles têm negados seus pedidos de permanência, e são deportados sumariamente, mesmo apresentando a ficha policial limpa antes requerida. É que o chefe de polícia sabia a penetração eas facilidades que estes africanos tinham no seio da comunidade escrava na Corte. ${ }^{21} 0$ medo se instala diretamente no coração da cidade.

0 final da década de 1820 e o início da seguintefoi de extrema politização de grupos subalternos normalmente alijados de qualquer articulação com o poder formal (cf. Ribeiro, 1991-1992). ${ }^{22}$ Lógico que 1835 também é um capítulo dessa trama, e el e não pode ser deslocado da conjuntura das rebeliões regionais como, por exemplo, a C abanagem, no Pará. Q uando um preto mina é preso por estar levantando uma "bandeira tricolor", símbolo da França revolucionária, em pleno centro do R io deJ aneiro, ésintoma dequea politização chegou a um grau intolerável para as camadas conservadoras da sociedade. ${ }^{23}$

$N$ ão eram apenas libertos africanosfugindo da repressão, ou fugidos embarcando clandestinamente nas rotas costei ras. Escravos implicados no movimento baiano eram levados pelos seus senhores para serem vendidos "Ionge da terra", e no Rio de J aneiro era onde se conseguiam tal vez os mel hores preços. I sto sem contar os crioulos da Bahia, que vinham na esteira da vaga africana e que facilmente se envolviam nos conflitos intestinos das comunidades negras na cidade.

Estudos Afro-Asiáticos, Ano 23, ํo 2, 2001, p. 12 
A Corte assiste, neste dias aflitos, a uma verdadei ra caçada aos minas. M esmo aqueles que aparentemente nada podiam contra o poder policial são presos como potenciais incitadores de possíveis levantes, como o cego Teotônio Antônio, preso pelo crime de "fazer adivinhação e dar fortuna" ${ }^{24} \mathrm{O}$ s libertos africanos ocidentais já estavam na mira das autoridades desde certo tempo. Já em 1830, as autoridades da Bahia tentavam limitar a mobilidade destes libertos, para impedir que al guns se tornassem elos de ligação entre comunidades distantes e, pior, estimuladores de revoltas que estremeciam as montanhas da província. ${ }^{25}$

0 fantasma do liberto africano verdadeiramente assombrava a C ortel mperial. A documentação reservada do chefedepolícia forma um testemunho candente daqueles dias agitados na capital do país. 0 Regente Feijó emite longa circular a Eusébio de Q ueiroz - quetambém serve para subdel egados ejuízes depaz - para ficar de sobreaviso quanto aos rumores de reuniões ou outros sinais inquietadores nas vizinhanças. A ordem énão ser surpreendido com a presença numerosa dos temidos minas e "tranqüilizar os ânimos dos habitantes desta capital que porventura possam estar receosos da possibilidade de reproduzirem-se nelas as cenas de horror que tiveram lugar na cidade da Bahia pela insurreição dos africanos". Recomendava aos Juízes de Paz para procederem aos "mais escrupulosos exames sobre os pretos M inas que possam residir em seus respectivos distritos, se na casa que habitam há reuniões de outros e por maneira que possam causar desconfiança" ${ }^{26}$ O M inistro da J ustiça planejava uma operação policial de grande envergadura, realizando batidas nas casas coletivas de africanos minas simultaneamente em vários pontos da cidade.

As autoridades policiais da Corte estavam por certo se baseando na experiência da polícia baiana, que desbaratou o esquema da rebelião exatamente quando se antecipou, obrigando os revoltosos a precipitar a eclosão da revolta, o quese revelou fatal para os conspiradores. N o Rio de Janeiro, os angus, ou zungus, casas coletivas de reuniões para africanos e crioulos, que já eram proibidos pelo menos desde 1833, podiam ser os centros nervosos de uma virtual explosão social, e por isso a pressão sobre elas se tornou cada vez maior. ${ }^{27}$

As casas de feitiçco, sempre vigiadas, mas de certa forma antes toleradas pela falta de evidência de ligações com a resistência direta, eram em 1835 focos perigosos. 0 sminasfeiticeiros, reconhecidos nas comunidades negras urbanas como cél ebres adivinhos e mágicos, sofreram implacável perseguição, nos cantos mais deser-

Estudos Afro-Asiáticos, Ano 23, ํo 2, 2001, p. 13 
tos da cidade. A região do $\mathrm{V}$ alongo, antigo ponto de chegada dos negreiros, também tinha suas "casas de feitiços" ${ }^{28}$ F oi numa delas que certamente o chefe de polícia encontrou o papel com os enigmáticos dizeres na língua malê.

$M$ as a histeria conspiratória não dava frutos. Asinformações queE usébio de $Q$ ueiroz eM anoel Alves B ranco, M inistro daJ ustiça, exigiam sobre uma larga rede de intriga montada pel os minas de um extremo a outro da cidade não chegavam (idem, Códice 334 , f. 10 v.; 8.3.1835) ${ }^{29}$ Entretanto, a cúpula da polícia na Corte não esmoreceu. Energicamente renovou seus pedidos aos subordinados, agora incluindo as irmandades de pretos, que pontilhavam na cidade velha. Com certeza o recinto sagrado de Santa Efigênia foi alvo das raziaspoliciais, que perscrutavam seusaltares ecapelas em busca de quaisquer indíciosquelevassem à "conspiração M ina" ou às célebres "reuniões secretas de homens de cor". Solicitava o chefe de polícia, através de circulares, a vigilância "deles, de dia e de noite, não só por meio de seus inspetores, como também pelos cabos de ronda e patrul has" e a confecção de "um mapa completo doshomens decor dos respectivos distritos", no qual "se declarasse seus nomes, condições, estado, modo de vida, naturalidade, qualidade e que se informassem sobre as irmandades religiosas que assistissem esta gente, em que dias [e] horas se reuniam, se contava que eles tinham al guma tendência sediciosa ou ensinam [sic] a fins políticos que pudessem ser perigosos a sociedade".

A gravidade do problema na Corte nos princípios de 1835 era tão assustadora que o próprio M inistro da Justiça passa a deliberar pessoalmente sobre a questão dos africanos M inas, deixando em segundo plano o chefe de polícia, normal mente a figura máxima nas questões de ordem pública na capital do I mpério. Este ofício enviado ao chefe de polícia - como outro secretíssimo - demonstra que o medo chegou com força e definitivo nos mais al tos níveis de Estado. Infelizmente não conseguimos localizar este "mapa". Seria um instrumento fantástico para local izar a distribuição do "perigo mina" nacidade do R io dej aneiro, emaisainda, um recorte inédito das comunidades escravas e africanas na $\mathrm{C}$ orte. ${ }^{30}$

A documentação policial sigilosa cita a chegada de um novo livro com "caracteres africanos" na mesa do chefe de polícia, resultado de uma das inúmeras batidas. Seria semelhanteao papel escrito com caracteres árabes que vimos acima, o amuleto falando em "guerra" que tanta aten ção mereceu dos mais al tosfuncionários da Secretaria de polícia da rua da G uarda Velha nos idos de fevereiro de 1835? Fica difícil ter certeza, mas a chegada deste misterioso li-

Estudos Afro-Asiáticos, Ano 23, no 2, 2001, p. 14 
vro só ocorreu em outubro, muitos meses depois, o que pode indicar que a comunidade malê continuou produzindo seus escritos, mesmo sob a pressão permanente das batidas policiais. Enviado pelo juiz de paz do 1o distrito de São J osé, era um "Iivro escrito com caracteres africanos" etemia-se que nele houvesse "doutrinas perniciosas quetanto podem comprometer as famílias e perturbar o sossego público como atestam os funestos exemplos que tem havido em algumas províncias e principalmente na Bahia" (AN RJ, Códice 334, 10.11.1835, f.14).

0 RegenteFeijó mandou decifrar o que parecia ser um código secreto dos pretos, quetinha de ser descoberto para barrar as comunicações entre os diversos núcleos da pretensa conspiração. Estrategicamente, deveriam ser primeiramente convocadas duas pessoas - certamente africanos - que "pareçam entendidos" e mandá-los "separadamente decifrar aqueles caracteres e observar se a decifração combina ou varia em pontos e sinais". D everia haver muita cautela e também recursos extras para tais investigações. Restam poucas dúvidas de que o livro foi escrito no alfabeto árabe dos minas-malês.

N os últimos dias de 1835 seriam determinadas ao Juiz de Paz de Santana investigações junto a uma casa da R ua L arga de São J oaquim onde parecia haver "reuniões de pretos M inas, a título de escola de ler eescrever". Tais encontros eram realizados diariamente, à tarde. $\mathrm{N}$ a mesma freguesia, na ocasião, um outro alvo da repressão foi o preto mina M anoel. Em sua casa, rua F ormosa da C idade N ova - havia suspeitas de "reuniões" de "pretos de mesma nação", além de eleser conhecido como curandeiro (cf. Chalhoub, 1990:187-188). Antes de 1835 não existem evidências de escritos feitospor escravos na cidade do Rio deJ aneiro, ejá vimoso quanto o perigo malêse encarna nos sinais e indícios encontrados pela polícia. As medidas do M inistro de separar os intérpretes era uma cautel a contra possíveis burlas dos africanos tradutores, que poderiam assim ajudar seus companheirosenvolvidos. A téo final da dé cada outros escritos $M$ inas ainda atormentaram as autoridades (AN RJ, Códice 323, V.14, 24.1.1839, f.12). ${ }^{31}$

Vemosassim que o fantasma queassolavaa C ortenão eraum problema local, ou mesmo baiano, mas uma questão mais ampla, que abarcava grande parte do I mpério. A imagem que nos vem utilizando o jargão médico que começava a entrar em voga neste momento - éque o império sofria uma contaminação generalizada, por conta do expurgo ocorrido na cidade de Salvador, eesta infecção se somava com outras real idades preexistentes de protestos

Estudos Afro-Asiáticos, Ano 23, ํo 2, 2001, p. 15 
escravos. Ascrises políticas regenciais, como no Rio G rande do Sul e no Pará, contribuíam para agravar ainda mais as expectativas.

$M$ as a Corte constituía-se numa caixa de ressonância. Um grande levante escravo no coração da capital podia estimular uma sucessão de insurreições por todo o país, que no mínimo comprometeria a estabilidade da instituição escravista, e no máximo 0 próprio regime político vigente. A Corte era um dos focos preferenciais destemovimento continental. Já sefal ava nas ruas quetrês mil negros pegariam em armas ao explodir o levante. E inclusivese tinha até divulgado o local onde se iniciaria a rebelião: a freguesia de São José, um dos locais prediletos para moradia dos minas (AN RJ, Códice. 334, 18.12.1835 e 22.12.1835, f.17).

U m dos exemplos de como as informações chegavam desencontradas às autoridades foi relatado pelo próprio $\mathrm{M}$ inistro dos $\mathrm{N}$ egócios Estrangeiros, J oão Francisco Carneiro de C ampos. Ele recebeu uma carta anônima de um cidadão relatando como soube dos rumores de levantes que ocorreram na cidade. 0 denunciante anônimo estava andando pela cidade, até por questão de saúde, quando chegou a uma casa de negócios no Largo do C apim que pertencia a AndréAvelino Rodrigues, irmão do $M$ arechal $M$ anuel J orge Rodrigues. 0 caixeiro da casa então revel ou queuma terceira pessoa "de caráter e bem intencionado" Ihe avisara que o número de negros prontos para iniciar o movimento chegava a três mil, e mostrou ao informante uma carta que escrevera para um seu irmão, avisando da proximidade do levante. 0 denunciantediziaestar fazendo isto "pela pública causa do B rasil" e para ajudar a evitar a "tal desgraça". Pedia para o M inistro ocultar seu nome e pensar na "prosperidade do império", tomando as medidas cabíveis (idem, s/d., f. 16, AN ). Era este o clima em dezembro de 1835, um final de ano com muita agitação.

$M$ as não era apenas na C orte que o caldeirão fervia. 0 presidente da província do Rio de Janeiro enviou um ofício sigiloso ao $M$ inistro da Justiça dando conta de um plano urdido entre escravos das áreas rurais eaqueles da cidade para seunirem numa potencial rebelião. N ão só isso. Ele já tinha informação do nome de um dos cabeças do movimento: um tal Andrade, pardo forro, que tinha casa de quitandas na rua do Rosário. Para agravar ainda maisa tensa situação, denúncias de uma organização secreta orquestrada por ciganos e pretos forros para roubo de escravos e o envio dos mesmos para fazendas do interior fecha a agenda política do atribulado ano de $1835 .^{32}$

Estudos Afro-Asiáticos, Ano 23, ํo 2, 2001, p. 16 
U m recurso usado cada vez mais pelas autoridades do Rio de J aneiro e principalmente da Bahia para se livrar de libertos minas incômodos foi a deportação para a África. A Assembléia Legislativa da B ahia, também em 1835, chegou a solicitar a criação urgente de uma colônia em al gum ponto do litoral africano, visando o repatriamento dos africanos livres e alforriados (cf. Cunha, 1985:77). N o pós-1835, um crescentefluxo - que podemos chamar derefluxo, parafraseando PierreVerger ${ }^{33}$ - de africanos libertos cruza o Atlântico, geralmente para Angola, mas também aportando em Serra Leoa e até M oçambique (J ornal do Commércio, $5 / 2 / 1836)$.

U m destes navios, para azar e pânico das autoridades policiais na Corte, teve problemas em alto mar, e foi obrigado a entrar na barra para realizar reparos. Trazia 46 "pretos forros de nação $M$ ina" entre homens, mulheres e crianças. Todos apresentavam passaportes rubricados pelo chefe de polícia de Sal vador. M as não adiantou. Eusébio de Q ueiroz foi terminante em proibir, de qualquer modo, o desembarque dos minas do brigue português Funchanlena. 0 máximo que permitia era a transferência para outro navio, mas pisar em terra jamais. 0 chefe de polícia sabia que os minasiriam encontrar umavastacomunidadedeiguaisna Corte, e quedificilmente eles seriam pegos aqui. 0 safricanos só tiveram do Rio de J aneiro a vista. Em 21 de dezembro o brigue levantou âncoras (AN RJ , Ij6 171, ago./dez.1835, 4.12.1835 e 21.12.1835).

Ao receio das autoridades com os minas se somava a preocupação com o tráfico clandestino de africanos. 0 número de africanos desembarcadosestava aumentan do, mesmo com toda a repressão. A legislação passa a controlar cada vez mais de perto negros vindos em navios mercantes ou mesmo de guerra. $M$ as a diferença básica entre africanos boçais a bordo de negreiros e africanos da C osta daM ina "Iadinos", epor isso mais perigosos, não escapavaàs autoridades.

$\mathrm{N}$ a realidade, as autoridades do Rio de J aneiro estavam lutando em duas frentes: de um lado africanos minas, escravos vendidos para a Corte por proprietários baianos temerosos; de outro, africanos minas, libertos, que por seus próprios recursos se movimentam num verdadeiro êxodo para a capital do Império. Para melhor racionalizar a repressão, era preciso tratá-los com cuidados semelhantes. 0 s direitosque deviam ser reconhecidos a um liberto ou livre tinham de ser esquecidos. 0 clima na C orte de $1835 \mathrm{em}$ diante se assemel hava a uma guerra étnica con tra uma nação determinada. 0 utras nações parecem ter sido esquecidas no furor re-

Estudos Afro-Asiáticos, Ano 23, ํo 2, 2001, p. 17 
pressivo, apesar de o perigo mina poder ser lido como uma ameaça de articulação de todas as nações mantidas no cativeiro.

$\mathrm{N}$ a prática todos os africanos e crioulos vindos da Bahia caíam na mira das autoridades policiais. Em janeiro de 1836 uma pista concreta chega nas mãos do chefe. D entro do boné de um preto revistado por uma patrulha de polícia na freguesia de São J osése encontraum papel com instruções sobreuma possível rebelião no natal de 1835. O rdena-seimediato interrogatório do preto ese enviam ofícios aos subdelegados para ficarem de prontidão. A descoberta de um plano de insurreição escrava em Sacra Família, província do Rio, no mesmo momento, era a conexão conjunta do levante que se temia. ${ }^{34}$

$M$ as não era só o fantasma da rebelião dos malês que atormentava as autoridades. A revolução dos cabanos no Pará também chegou aos corações e mentes da população negra na Corte, como já destacamos no episódio com Felipe M oçambique. Em abril de 1836, um africano liberto denação moange, denomeAdão J oséda Lapa, dono decasa de quitandasna rua da G uarda Velha, ao ver sua moradia invadida por policiais disse que arbitrariedades iguais “já deram cabo do Pará eestes atos já tem posto o Rio de aneiro no estado em que se vê". ${ }^{35}$

Estas advertências podiam ser leituras diferenciadas de escravos e libertos que traduzem em síntese uma destacada diferença: enquanto o levante malê de 1835 conheceu fracasso, abortado pela del ação, o movimento dos cabanosem 1836 ainda era vitorioso, expulsando a elite senhorial da capital da província e efetivamente tomando o controle da região. Estas diferenças com certeza estavam presentes na mente de africanos, crioulos, libertos, escravos e homens livres pobres. N este mesmo contexto, aliás, sai a primeira deportação de africano ocidental na Corte: Antônio N agô, vindo da Bahia, e preso sem passaporte. Antes, José M ina, escravo deum tenentetinhasido encontrado em Santa Rita com quatro espingardas e três pistolas. 0 chefe de polícia considerou o caso gravíssimo. ${ }^{36}$

Seduções e I dentidades

A presença dos africanos ocidentais, os minas, não foi só em Salvador e Rio de Janeiro. Eles aparecem em outras cidades escravistas brasileiras já no período colonial, assim como em áreas rurais e mesmo em quilombos. I nês O liveirajá demonstrou como os

Estudos Afro-Asiáticos, Ano 23, ํo 2, 2001, p. 18 
minas e outros africanos ocidentais poderiam ser classificados em termos étnicos para a Bahia nos sécul os XVIII eXIX (cf. O liveira, 1997). A nalisando a população escrava de origem africana na Capitania de M inas G erais, também destacam-seas presen ças significativas de escravos, tanto trazidos da África 0 cidental - chamados também ali genericamente de minas - , como escravos provenientes do Centro-Sul daÁfrica, principalmente os angolas. Baseando-se em Boxer e R ussel-W ood, M ott argumenta sobrea predominância também de africanos oriundos da C osta da M ina na primeira metade do século XVIII, "apesar da significativa presença Bantu na maior parte das local idades e períodos da zona aurífera". $M$ ott chamou a atenção igualmente para o fato de o termo mina ser muito genérico (ver Boxer, 1963 e Russel-W ood, 1982 apud M ott, 1988:100-103). ${ }^{37}$ Embora as identidades étnicas dos vários povos africanos que vieram escravizados para o B rasil não possam ser desconsideradas na perspectiva de uma análise a respeito da constituição e organização de mocambos no B rasil, principalmente nos sécul OS XVIII ea primeira metade do XIX, já sugerimos como mocambos - e demos destaque para aqueles mineiros - foram formados por africanos dediversosgrupos étnicosemesmo escravos nascidos no Brasil. Sem generalizações, é possível argumentar que estefenômeno de complexidades étnicas africanas (etambém de crioulização) nos quilombos brasilei ros foi recorrente, podendo o impacto de um determinado grupo étnico africano ter ocorrido circunstancialmente numa ou noutra região e/ou período.

Ainda que com suas diferenças étnicas, lingüísticas e culturais, os africanos, tanto nos quilombos como nas senzal as, procuraram compartilhar objetivos e estratégias para conquistar - de quemodo escolhessem ou fosse possível - suas liberdades. Em alguns momentos, porém, tais diferenças podem ter atrapalhado. Em 1719, por exemplo, comentava-sea notícia de que os escravos minas e angolas preparavam um grande levante na C apitania de $M$ inas $G$ erais. Informações dadas ao C onde deAssumar revelavam que os escravos "tinham maquinado", para deflagrarem a insurreição "para a noite de quinta-feira santa, os negros do R io das M ortes, Forquim, 0 uro Branco, São Bartolomeu, 0 uro Preto ede outras partes". As autoridades descobriram a preparação desta insurreição com tempo suficiente para reprimi-la. Dizia-se, contudo, que os escravos acabariam tendo êxito caso não houvesse disputas étnicas, uma vez que "entre eles [havia] a diferença de que os negros de Angola queriam quefosse Rei de todos um do seu Reino, e os minas também de que fosse da mesma sua pátria". ${ }^{38}$

Estudos Afro-Asiáticos, Ano 23, ํo 2, 2001, p. 19 
M esmo não conseguindo os escravos uma aliança étnica forte suficiente para fazer deslanchar aquele levante, as autoridades coloniais mineiras ficaram sobressaltadas. Em 1725 já determinavam que os senhores destinassem para o trabal ho nas $M$ inas $G$ erais os cativos de natural idade angola, em detrimento dos minas, sob a justificativa de serem os primeiros mais "confidentes, mais sujeitos, e obedientes", enquanto queos últimos eram temidos pelo seu "furor, val entia", podendo assim "animar a entrar em al guma deliberação de se oporem contra os brancos". O s minas eram acusados igualmente de serem "feiticeiros" (cf. Costa Filho, 1960-61 apud M oura, 1972). É bom destacar que M alês poderiam não estar somente em Salvador. ${ }^{39}$ Para o Rio de Janeiro - e também para as áreas urbanas deSão Luíse Recife - também podemos considerar a presença de escravos africanos do Sudão C entral, islamizados, e exportados pelo G olfo deBenim, entreo final do século XVIII eas primeiras décadas do XIX.

Abordagens revisionistas têm analisado as implicações metodológicas de considerar a permanência de grupos étnicos africanos - aparentemente definitivos - a partir das experiências do tráfico e escravidão nas Américas. Tem sido fundamental relativizar os paradigmas da concen tração $\mathrm{x}$ dispersão e da heterogeneidade $x$ homogeneidade no sentido das denominações africanas ou "nações" em termos de nomenclatura e taxonomias étnicas. 0 caráter permanente das reconstruções deve ser avaliado, considerando, entre outras coisas, o número reduzido dos principais portos de embarques de africanos relacionados, em contraste com as vastas regiões africanas al can çadas pela rede terrestre do tráfico. D estacam-se, igual mente, as profundas diferenças entre os léxicos étnicos das várias micro-sociedades africanas, na visão dos traficantes, africanos ou europeus, e dos senhores (cf. Morgan, 1997:130-1, 136 ss.; ver, também, Gómez, 1998; H all, 1992; M ullin, 1992; Thornton, 1992). Africanos recém-chegados podiam conhecer vários caminhos visando, ao mesmo tempo, a sua "integração" nas sociedades escravistas e a sua inserção étnica, agenciando novos espaços de vida, trabalho eidentidade. Entreestes caminhos havia aquel es da ótica senhorial e aqueles das comunidades escravas em contextos específicos. Redefiniam-se as lógicas de dominação, assim como identidades e formação de comunidades escravas.

N um importante trabalho publicado recentemente, abrindo caminho para a retomada de debates e pesqui sas sobreidentidades africanas e crioulas nas experiências escravas, M ariza Soares

Estudos Afro-Asiáticos, Ano 23, no 2, 2001, p. 20 
apresenta os minas no Rio de Janeiro desde o século XVIII. Com fontes originais, $M$ ariza argumenta - destacando os limites para pensarmos "nações" africanas, considerando a fragmentação da documentação e as construções do tráfico negreiro - sobre a gestação de identidades dos minas esua articulação com irmandadese outras formas associativas (ver Soares, 2000). ${ }^{40}$ É certo que muito antes que o medo mina se instalasse na cidade do Rio deJ aneiro, os africanos ocidentaisjá ocupavam um lugar peculiar no meio da escravaria. Este lugar era marcado pelas alianças construídas pelos minas com outros grupos sociais, mesmo não escravos. Como explicar que funcionários do consulado da Inglaterra tenham enfrentado a temida I mperial G uarda de Polícia para salvar dois minas, pertencentes ao cônsul, que foram detidos pela mesma guarda? ${ }^{41}$ Esta proximidadeentreminas eas autoridades inglesas vai assumir sombrios contornos nos anos seguintes, quando cresce a pressão britânica contra o tráfico atlântico de africanos para o B rasil. $\mathrm{M}$ as para as autoridades 0 que real ça na personalidade dos minas era seu caráter rebelde, o que colocou em al arme os responsáveis pela ordem pública na cidade.

M últiplos, os africanos ocidentais ocupavam vários ângulos da preocupação senhorial e policial, como Apolinário M ina, que além de capoeira, foi preso por desobediência e resistência. ${ }^{42} \mathrm{De}$ certo esta versatilidade era uma rara qualidade entre as diferentes nações africanas, egarantiu aos minas uma invulgar penetração no seio da heterogênea comunidade escrava do Rio de Janeiro. Além disso, alguns eram familiarizados com a cultura letrada, herança das tradições muçulmanas em sua terra, e isto também Ihes conferia um papel especial, quando vemos a quantidade de requerimentos escritos por pretos minas para conseguir a sua liberdade, al go pouco comum na cultura afro-carioca do século XIX.

$M$ as os minas não encarnavam apenas o perigo da sublevação geral, mas também eram mestres de um outro ofício que provocava tremendas dores de cabeça nas autoridades esenhores da cidade: a sedução de escravos, que era uma forma de atrair o cativo com al gum artifício e depois enviá-lo - com inteira participação dos próprio escravo - para fora da cidade, geral mente para al guma fazenda ou mesmo para quilombos suburbanos. D iferente do roubo, a sedução muitas vezes era realizada com a partici pação ativa do próprio "roubado", o que nos permite colocá-la como mais um variante da fuga, mesmo que não representasse uma "negação do sistema".

Estudos Afro-Asiáticos, Ano 23, ํo 2, 2001, p. 21 
0 subdelegado da Freguesia de São J osé - onde se concentrava grande parte dos africanos ocidentais - foi o primei ro a protestar contra as repetidas solicitações de passe dos minas. Era para que pudessem ir para ao interior da província comprar galinhas que aparentemente pretendiam revender nas ruas da Corte, mas que na realidade, pel o ol har desconfiado do subdelegado, era tudo pretexto para permitir que os minas percorressem as senzalas da província, "convencendo" seus moradores a irem para a Corte, onde os esperava uma densa comunidade africana e tal vez a liberdade. ${ }^{43}$ As seduções de cativos estavam neste momento se dando no sentido do campo para a cidade. I sto é, havia diversos cativos defazendas interessados em usufruir das possibilidades de trabalho e socialização quea cidade permitia. Esta rota do campo para a cidade vai engrossar nas décadas seguintes.

Assim, a partir dos anos 1840 vemos como os minas no Rio, antes de se tornarem os líderes da temida rebelião, estavam se tornando os artífices da sedução, gozando de um incomum prestígio frente às outras nações de escravos, al gumas pouco predispostas à confiança mútua. Também não pode ser esquecido que muitos minas eram libertos, cujo controle era muito mais difícil do que dos cativos, daí a novidade da medida requerida pelo subdelegado. Assim, vemos como os minas abrem mais um canal de comunicação entreescravos da cidadee do campo, estreitando relações entre os dois mundos, afinal mais próximos do que supõe a historiografia sobre escravidão.

A sedução ocorria também dentro da cidade. 0 intrincado labirinto de becos e vielas fazia com que fosse fácil ocultar um escravo, atéque fosse possível mandá-lo para fora da cidade ou mesmo que ele se mantivesse como forro em algum subúrbio distante ${ }^{44} \mathrm{~A}$ rede de sedução de escravos montada pel os minas nunca foi devassada em sua plenitude. ${ }^{45}$

Em outras partes do I mpério os ventos da sedição ainda corriam na direção dos minas. Informações de uma conspiração de "homens de cor" no R io G rande do Sul capitaneada por pretos minas mostram queo êxodo não sedirigia somentepara o R io, mas se espal hava por outras províncias, já estremecidas pelas convulsões da era regencial. A informação de uma "conspiração da gente de cor" arquitetada por dois pretos minas, revela que tais temores já eram interprovinciais. ${ }^{46}$

A questão dos minas era ampla, e por mais que na C ortetalvez tivessem mais projeção - pelo papel político da capital e a grande população negra e africana ali resi dente - era nas provín-

Estudos Afro-Asiáticos, Ano 23, ํo 2, 2001, p. 22 
cias mais estremecidas pelos movimentos políticos queeles encontravam facilidade para se esconder em meio à população escrava, e talvez maior impacto de suas ações. $\mathrm{N}$ a C orte, 0 medo da rebelião generalizada diminuía com o correr da década, mas os ataques contra senhores por escravos minas reforçavam a aura de rebeldese incorrigíveis queestes africanos gozavam entrea população branca eproprietária. ${ }^{47} \mathrm{O}$ scasos se sucediam, reforçando afama deincontroláveis que tinham os minas.

A mobilidade destes africanos ocidentais pelas rotas litorâneas de cabotagem entreas cidades do império era impressionante. M as o retorno para a África também não era raro, e há fortes indícios da existência de uma rota subterrânea para este continente aberta principalmente para os libertos. Africanos navegando nos dois sentidos do Atlântico não era raro, mas parece que entre os minasnovamenteo quese suspeitaédeuma rededecumplicidade, oculta dos ol hares da polícia, semel hante àquela que leva escravos para dentro e para fora da cidade. ${ }^{48}$

A denúncia in sólita de que africanos livres M inas "sedutores" de escravos estavam indo e voltando da Costa da África revela o quanto a rede oceânica tecida pelo tráfico negreiro podia ser reutilizada por libertos no sentido de ligar margens do Atlântico (AN RJ, Ij6 194, jun./dez. 1839, 31.7.1839). Curioso também éo castigo oferecido pelo Chefe de Polícia, Eusébio de Q ueiroz, a estes "sedutores": a deportação para a África. I ronicamente a lei que jogou na ilegalidade o tráfico atlântico previa que os africanos livres capturados na repressão fossem retornados para a costa de onde embarcaram.

0 que primeiro real ça desse ofício do chefe de polícia Eusé bio de $\mathrm{Q}$ ueiroz para o $\mathrm{M}$ inistro daJ ustiça éa presen ça de africanos livres entre os minas da Corte, como fica claro quando se menciona que seus serviços foram "arrematados". C omo se sabe estes africanosli vresficavam sob a custódia do governo, mas por negligência - ou interesse - muitos desapareceram depois deentreguestemporariamente a proprietários de prestígio, que deveriam "educá-los" e alimentá-los. M as a grande maioria se perdeu no meio da escravaria que vagava pela cidade. ${ }^{49}$

Eusébio de Q ueiroz sabia também que os africanos contrabandeados pelo tráfico ilegal não podiam ser considerados meros boçais, incapazes de qualquer articulação com outros agentes sociais, mas que eles perceberam de sua condição limite, e lutariam pela efetivação de sua liberdade, como aconteceu várias vezes na segunda metade do século XIX. Ao comentar a legisl ação que proi-

Estudos Afro-Asiáticos, Ano 23, ํo 2, 2001, p. 23 
bia o tráfico de africanos para o Brasil, o chefe de polícia em 1833 avisou que um dia os african os contrabandeados perceberiam que antes de serem "peças" eles tinham sido ilegalmente contrabande ados, e que os senhores nesse dia estariam muito próximos de perder suas "peças" sem que os agentes do Estado pudessem fazer coisa alguma. ${ }^{50}$

O s minas africanos livres aparentemente conheciam melhor sua ambígua condição, e jogavam com este estado sui generis para viver na prática apartados de seus senhores, em seu ambiente preferido: a vasta malha urbana escrava do Rio de J aneiro. A sedução era obviamente uma atividade marginal, mas com certeza seus serviços eram cobiçados por ciganos e até escravos ansiosos para deixar a cidade pelo campo, ou vice-versa.

Talvez a condição ambígua de africano livre - al guém que teoricamente era livre, mas vivia as mesmas agruras dos escravos, sob jugo senhorial - ajudasse na penetração deles dentro da comunidade escrava em geral. M as o fato éque os minas - independente de serem escravos, libertos, livres ou africanos livres- gozavam de certo "passe livre" na babel de línguas e culturas que era cidade africana do Rio. Aliás, num recente artigo, Beatriz M amigoniam explora as estratégias dos minas, especialmente os africanos livres, inventando suas escravidões eemancipação (ver M amigoniam, 2000).

Certa feita Eusébio de Q ueiroz vislumbrou o vasto esquema da sedução de escravos montado pel os minas na cidadedo Rio. U m ofício do presidente da província do Rio mostrou ao chefe de polícia que tudo que ele vira antes era apenas a ponta do iceberg. Era 0 caso de uma escrava chamada $C$ atarina $C$ assange, pertencente $a$ um tal $M$ anuel da Rosa, eque fora seduzida na $C$ orte por um preto mina denomeAleixo, oficial de barbeiro emorador na rua dosFerradores. Junto com outro escravo - também seduzido - eles foram enviados para G uapy, distrito de M agé, na Província do Rio, e entregues a J oaquim $M$ ina, que tinha uma venda naquela região.

Era a ponta do outro lado da rede. $M$ as a história não terminou. C atarina ainda foi enviada para um quilombo em um lugar denominado Laranjeiras. Ali deu à luz uma criança, e depois foi enviada a um certo Parnaso, administrador de uma fazenda pertencente a um tal $\mathrm{D}$ amião. A negra recebeu ali outra criança para cuidar - talvez o preço da estadia - e os dois foram batizados na vila de $M$ agé, junto com outra "cria escrava" do Parnaso. ${ }^{51}$ Além disso, o tal Joaquim M ina - conexão rural da rede mina de sedução - comprava a lenha oriunda do quilombo e tinha "bastantes

Estudos Afro-Asáticos, Ano 23, ํo 2, 2001, p. 24 
"Com o Pésobreum Vulcão" : Africanos M inas, I dentidades...

relações com os habitantes dele". V emos assim montado um quadro que podedefinir os caminhos da sedução de escravos: africanos minas bem localizados na Corte, donos de vendas e tabernas nas zonas defazendas, quilombosocultosnas serras, protegidos - talvez por um pacto de colaboração - por administradores e afinal escravas domésticas arranjadas no mercado paralelo, por preço bem mais acessível, em tempos de tráfico clandestino. D ificilmente a rota seria cumprida sem livre e espontânea vontade da escra $\mathrm{va}^{52}$

Esta vasta rede ligando quilombos suburbanos com as movimentadas ruas da C orte era também articulada pel os minas, e não vemosestrutura semel hanteantes da chegada deles em grandes númerosno Rio após 1835. Por maisqueo espectro da rebelião ainda seguisse os minas, era nos subterrâneos da sedução de escravos e da organização clandestina que eles fizeram sua fama, e ao dissabor das diferentes autoridades. N os anos 1840, a deportação dos minas para a África - principalmente Angola - tornou-se uma arma efetiva das autoridades, como no caso de Alexandre e Salvador, levados para B en guela como castigo por seus crimes contra a "propriedade". ${ }^{53}$

0 apogeu dos minas na Corte do Rio de Janeiro foi a década de 1840. Para onde o ol har das autoridades se dirigisse lá estavam: como líderes de virtuais levantes imaginados, chefes de grupos perdidos no emaranhado de casas, ou provedores de redes de contrabando de cativos entrea cidade e as fazendas. M as os minas não eram apenas "sedutores". Eles também eram "seduzidos" e assim também entravam na circulação clandestina da mercadoria escrava, como Sabino M ina, que confessou ter sido roubado na Bahia por um guarda nacional (AN RJ, Códice 323, V.16, 18.11.1841, f.44).

0 sminas que causavam maiores problemas aos fiscais da ordem pública eram os não escravos: libertos, livres, africanos livres. Estes usufruíam de uma mobilidade que permitia grande versatilidade dentro e fora dos mundos da escravidão. U m caso extraordinário foi o de Felício. Tinha sido, inicialmente, entregue como afri cano livreao político J oséPaulo $\mathrm{N}$ abuco deA raújo - talvez parente do político José Tomaz $\mathrm{N}$ abuco de Araújo, pai do abolicionista joaquim $\mathrm{N}$ abuco. D epois de "bons serviços" ele subitamente muda, na visão do consel heiro, e se torna rebelde. 0 conselheiro então envia uma representação ao chefe de polícia requerendo a deportação do africano mina para fora do I mpério com receio de vingança de parte de sua antiga “peça”. ${ }^{54} \mathrm{O}$ u seja, em 1831, Felício

Estudos Afro-Asiáticos, Ano 23, ํo 2, 2001, p. 25 
foi entregueao senhor Paulo $\mathrm{N}$ abuco, possivel mentecapturado na repressão ao tráfico, vindo do norte da linha do Equador, proibido desde 1815, já que nesta data a lei ampla de novembro de 1831 ainda não fora decretada. A pós uma fuga malsucedida, é levado para a C asa de C orreção, onde passa pelas agruras que esperavam os fugitivos. N unca mais, na opinião de seu senhor, ele voltaráa ser o mesmo (AN RJ, Ij6 202, 1844, 27.7.1845).

Como podia um cativo que duranteanos tinha se comportado da forma mais "dócil" na visão senhorial se tornar o símbolo do rebelde, do insurreto? Este exemplo é um momento perfeito para perceber como as leituras de "comportado" e do "incorrigível" podiam ser acopladas em um mesmo personagem, variando somente as circunstâncias exteriores. Assim os tipos sociais tão falados do "Pai J oão" edo "Zumbi", supostos paradigmas dos extremos da escravidão, na realidade eram apenas diferentes conjunturas, que podiam ser amoldadas, inclusive, pela vi são dos escravos (ver Silva, 1989). N o caso, Felício se comportou nos moldes prescritos pela ordem senhorial enquanto esta atitude podia refletir em ganhos, mas mudou radical mente quando percebeu possi bilidades mai oresdeagenciamento com a fuga (cf. C arvalho, 1998, esp. cap. 13).

Seria Felício M ina um africano livre que se "Iadinizou", usando a terminologia do próprio chefe de polícia vista acima, e descobriu seu verdadeiro espaço dentro da sociedade? D ifícil dizer sem contextual izar com a situação política vivida que na década de 1840 era muito agitada ede extrema politização. V alea pena destacar que o africano Felício foi entregue ao seu senhor numa quadra turbulenta da vida social no Rio de Janeiro. D epois da "hospedagem" da Correção passou um ano sofrendo de "reumatismo" possivelmente seqüelas dos castigos sofridos na prisão. A pós ser tratado voltou a fugir e depois capturado. Recal citrante, passa a hostilizar outros escravos da casa, tal vez acomodados demais a sua condição, para ele. Felício termina pedindo asilo na casa de um curador, de onde se comprometeu a manter os pagamentos do "jornal" ao seu senhor, como todo cativo deganho. No final, o mina afirma queficaria sob custódia do curador "enquanto os ingleses o não vinham buscar para protege-lo".

A partemais extraordinária dessa passagem éa rara leitura de um africano sobre a presença inglesa na repressão ao tráfico clandestino. Tal fala do africano deixa claro que os ingleses são lidos como aliados dos cativos e que podiam ser agenciados para ajudar a pender para o lado desejado os conflitos com o senhor. Assim, africanos capturados pela C omissão M ista Brasil-Inglaterra eram,

Estudos Afro-Asiáticos, Ano 23, ํo 2, 2001, p. 26 
nesta visão, protegidos da crueldade senhorial. Este recurso - ou esta possi bilidade - era aberta através do curador dos africanos livres que voluntária ou involuntária intermediava esse mecanismo (cf. Rodrigues, 2000).

Esta é uma clara percepção dos aliados possíveis nas leituras das experiências do cativeiro, uma visão política de que há brancos que podem trazer ben efícios à liberdade, e há aquel es que são inimigos inconciliáveis - no caso, o consel heiro N abuco de Araújo. $M$ as o relato do consel heiro do I mpério não tinha acabado. N o re lato de $\mathrm{N}$ abuco, este africano era a prova da incorrigibilidade dos minas da África $O$ cidental, pois conseguiu provocar o temor do seu próprio Curador, que pede a polícia proteção contra o africano livre. Assim Felício acabou de novo na C asa de Correção. Curiosa também é a negociação à distância entre o mina "colocado ao ganho" eseu virtual proprietário, que denota a margem que estetipo de ocupação escrava permitia frente ao senhorio. D igno de menção também é uso de cartas pelo africano mina, não só para o senhor, mas também a familiares e adversários. Estas cartas visavam na certa semear a cizânia entre amigos e clientes do poderoso político, uma arma inesperada para uma população quase inteiramente analfabeta. ${ }^{55}$

Causa espécie também ver um político renomado como um consel heiro do I mpério desistindo da queda debraço com um reles escravo, já que depois $\mathrm{N}$ abuco desistiu, remetendo definitivamente o mina para a C asa de Correção. D e acordo com ele, nas várias visitasquefez à Correção para comprovar seo negro tinha dobrado sua espinha, ele confessou que "jamais o viu disposto a humiIhar-se, achando-o sempre altivo, negando-se a fazer qualquer serviço que o humilhe".

Felício é o protótipo do que durante anos será o africano mina autêntico, na visão dos viajantes e contemporâneos: altivo, inteligente, enérgico, decidido, euma outra faceta pouco conhecida, profundamente político no sentido de negociador, articulador. Parece que o C onselheiro $\mathrm{N}$ abuco de Araújo encontrou na senzala um rival àaltura. $M$ as as condições do africano vão se degradando, suamargem demanobradiminuindo. 0 medo do consel heiro, porém, era ainda maior, ele pedea deportação de Felício para Angola ou Serra Leoa.

A legislação sobre africanos livres estabel ecia o prazo de "serviços" por 15 anos, que já estava terminando por volta de 1844 quando o livreé afinal deportado. M as é real mente marcante o temor que $\mathrm{N}$ abuco de Araújo nutria pelo ardiloso Felício Mina,

Estudos Afro-Asiáticos, Ano 23, ํo 2, 2001, p. 27 
principalmentequando ele se tornasse livre de todo, el eque deveria ter sido um dos primeiros africanos a entrar na condição delivre pela C omissão M ista, a julgar pelo número 13 da matrícula.

Afinal Felício foi deportado para Angola. ${ }^{56} \mathrm{~A}$ proverbial habilidade deste mina não era um caso isolado. U m ano depois um outro mina, $\mathrm{H}$ enriqueJ osé, concentrava as preocupações das mais al tas autoridades da justiça e da polícia do I mpério. 0 novo chefe de polícia da Corte, Luís Fortunato de Brito Abreu enviou, em 1845, um longo ofício ao M inistro daJ ustiça apresentando $\mathrm{H}$ enrique J osé, mais um preto mina no centro das atenções, e que também deveria ser deportado (AN RJ, Ij6 204, maio/dez. 1845, 30.6.1845).

$H$ enrique não era um africano livre, mas sim um liberto, porém estedetal henão diminui sua periculosidade frente aos ol hares da cúpula da polícia carioca. A prisão não era castigo bastantepara ele, no ol har das autoridades, daí o recurso extremamente usado nesta década da expulsão do I mpério. No caso do "Riscadinho" (seu apelido pode ser derivado das marcastradicionais do africano mina, que são três riscos no rosto ${ }^{57}$ ) o temor era tão grande que 0 chefe de polícia pediu sua deportação para no máximo 48 horas após a prisão.

D iferente de Felício, um mestre na arte da fuga e da intriga, H enrique era uma liderança na rede de sedução de escravos, quejá vimos acima, e tinha sua base de operações nas casas de angu, ou zungus, para onde africanos e crioulos convergiam. O s cativos "seduzidos" eram levados para estas casas, e depois clandestinamente dirigidos, por terra ou por mar, para fora da C orte, onde eram entregues para outros senhores ou introduzidos em quilombos ou "ajuntamentos" de negros nos subúrbios, como ocorreu - já destacamos - com Catarina Cassange, como já colocamos. Para agravar ainda mais o quadro: "Riscadinho" era um informante da polícia que, segundo relato de seu superior hierárquico, não era confiável, pois era um dos líderes das então cél ebres casas de pombear da C orte Imperial, um outro nome para os zungus. ${ }^{58}$

$H$ enrique "Riscadinho" era um informante de polícia ${ }^{59}$ mas pelo jeito utilizava sua posição para se beneficiar e, quem sabe, fornecer informações para as comunidades escravas e africanas urbanas, como um autêntico agenteduplo. M erece destaquea parteem que o chefe de polícia descreve as habilidades do africano, talvez num discreto gesto de admiração à quem enganou a polícia "tantas vezes". Em nenhum outro documento policial do Rio de Janeiro da primeira metade do século XIX percebemos uma autoridade

Estudos Afro-Asáticos, Ano 23, ํo 2, 2001, p. 28 
tão poderosa como o Chefe de Polícia da Corte descrever de uma forma tão impressionante as qualidades de inteligência e habilidade de um negro africano da Costa da M ina.

0 tributo pago pela autoridade-mor da ordem policial na cidade à esperteza de "Riscadinho" é um testemunho do quanto os escravos e os africanos, em particular os minas, alcançaram um al to patamar deliderança e experiência. Enquanto nos primórdios do século XIX tínhamos somente rápidas passagens nos livros de prisões de africanos, agora as autoridades dedicam verdadeiros relatórios aos ousados minas, e seu proeminente papel na mudança da política escrava na cidade do Rio.

0 último africano-ocidental desta galeria é aquele do qual menos temos informações. Cesário M ina aparentemente foi um recém-alforriado que depois da assinatura da carta de liberdade não cumprira seus "deveres" deliberto, como continuar prestando serviço ao senhor, e reverência por sua nova condição de "dependente". Passou a ameaçar seu ex-senhor, o qual pediu o castigo rotineiro: deportação para a África. ${ }^{60}$

0 chefe de polícia assumira por inteiro a visão do negociante, de nome J oão J osé Pereira, einsistira com o M inistro daJ ustiça para efetivar a deportação ${ }^{61}$ C esário afinal foi deportado paraBenguela (AN RJ, Ij6 211, 1848, 26.1.1848), juntou-se a talvez vasta comunidade de $\mathrm{M}$ inas em Angola, apesar de que alguns não tiveram esta sorte. ${ }^{62}$ Seria interessante um estudo sobre esta comunidade de "retornados" de africanos minas em Angola, quem sabe nos moldes dos retornados da Costa da M ina ainda nos finais do século XIX.63

$M$ as o que nos interessa é que o medo em relação aos minas era tamanho que haviam fundados receios que mesmo presos eles ainda continuariam exercendo funções deliderança na comunidade de africanos e crioul os da C orte. A deportação para a África podia ser vista por al guns membros da elite branca como um prêmio para os genericamente chamados de "africanos", mas era melhor do que ter cérebros ardi losos e perigosamente intel igentes na direção de uma vigorosa comuni dade negra no coração de uma cidade coal hada de africanos e escravos.

A atração que a cidade exercia sobreminaslibertos - consequência, entre outras coisas, do vasto corpo social de semelhantes vivendo dentro de seus estreitos limites - era tamanha, que eles desafiavam todas as regras para usufruírem dela. Como então explicar queC esário tenha conseguido, dez meses depois, voltar para a Corte? Teria vindo num navio negreiro clandestino? Teria arran-

Estudos Afro-Asiáticos, Ano 23, ํo 2, 2001, p. 29 
cado colaboração dos nativos de Angola para embarcar numa belonave mercante? $?^{64}$

Q ue estranha atração era esta que a Corte exercia sobre os minas da Bahia? O Rio de Janeiro na primeira metade do século XIX éa maior cidade africana do mundo Atlântico, mas esta leitura não era resultado apenas de números populacionais, mas sim de política. Talvez em nenhum outro lugar do 0 cidente se podiam forjar lideranças dentro do mundo urbano escravo e africano que polarizassem uma massa tão grande em um espaço tão limitado.

O s minas ficaram célebres nas Ciências Sociais por seu exclusivismo étnico, mas no Rio de Janeiro eles exercitavam exatamente o pendor contrário, entrando e saindo de todas as tribos, dialogando com todas as nações, construindo vasta clientela, dentro e fora da escravaria, e intimidando por seu prestígio a arrogância de certos senhores. Seu poder não era pessoal, mas fruto da base social interétnica quetinham por trás. Em suma, nosanos 1840 os minas corporificaram a liderança política da escravidão urbana, antes deles tal vez difusa e fragmentária.

A té a metade do século os africanos minas eram um destacado fator de preocupação ereceio por autoridades esenhores do R io deJ aneiro. Somente quando o tráfico atlântico cedeu - e os africanos passaram a ser vendid os para as grandes fazendas do interior - é que o "perigo mina" começou a diminuir paulatinamente. M esmo assim, atéo final da instituição da escravidão na cidade, os minas eram um referencial de liderança política ainda ameaça dor. $^{65}$

N o crepúsculo da primeira metade do século, em 1849, com seus renovados temores - forças navais inglesas pressionando pelo fim do tráfico, escravaria inquieta nas senzalas do café - 0 chefe de polícia da Corte enviou um longo relatório ao agora $\mathrm{M} \mathrm{i-}$ nistro daJ ustiça, Eusébio de Q ueiroz, conhecedor como ninguém do "perigo mina", demonstrando a complexa organização que os minas da Bahiatinham construído na Corteem 15 anos deexílio.

Verdadei ras sociedades secretas se ocultavam nas brenhas da cidade, aparentemente com destinação religiosa, mas o que era mais aterrador, manten do vasta correspon dência com comunidades do mesmo tipo em outras províncias, como Bahia e M inas $\mathrm{Ge}$ rais, e possivelmente na língua árabe, pois de acordo com o chefe de polícia as cartas eram redigidas em "escrituras de cifras". Tudo indica que nesta época os africanos ocidentais da Bahia tinham montado uma vasta rede que se espalhava por ampla parte do Império, quemesmo não voltada para o fim deuma rebelião gene-

Estudos Afro-Asiáticos, Ano 23, ํo 2, 2001, p. 30 
ralizada, já representava por si só uma ameaça para a ordem que se queria manter (D iário do Rio de Janeiro, 5/12/1849:4).

Em 1849, o medo da repetição do levante malê na C orte tinha recuado, mas a capacidad e organizativa destes minas era ainda um portento, esua habilidade em ocultar estas estruturas dos ol hares da repressão, magistral. M as - talvez para alívio dos africanos minas - o responsável pelo policiamento da capital concluiu que os papéis tinham apenas função religiosa, com preces do Alcorão, isso tudo talvez com a cumplicidade detradutoresafricanos. Seráo mesmo ardil utilizado com o temido Eusébio de Queiróz em $1835 ?$

D e acordo com o relato do então chefe de polícia, Antônio Simões da Silva, a partir do Rio de J aneiro esta rede estendia seus tentáculos até as províncias vizinhas, talvez utilizando códigos sociais invisíveis para as autoridades, apesar de o alfabeto árabejá ser delonge conhecido das autoridades, numa autêntica rede de casas de culto, talvez irmã da rede de sedução. 0 certo é que o medo guiou os agentes da repressão. Parece, contudo, que a batida da polícia não teve muito resultado, pois os africanos detidos foram libertados. Aparentemente o chefe de polícia Simões da Silva encontrou em 1849 as mesmas barreiras que Eusébio em 1835 ao tentar decodificar o complexo código de significados da língua malê. M esmo entendendo o sentido literal das palavras, eles foram, tudo indica, incapazes de perceber os sentidos políticos ocultos nos papéis mal ês, que apontavam os rumos, contraditórios ou não, da cultura política dos escravose africanos. ${ }^{66} 0$ chefe de polícia, porém, não deixou de considerar a tradição rebelde dosminas, e decidiu não tirar os olhos deles, ordenando que fossem vigiados deperto. E também não Ihe escaparam os vínculosinevitáveiscom a escravidão. Antônio Simões foi perspicaz o bastante para entender o vínculo entre reli gião erevolta, tão importanteem 1835, eno final de seu longo ofício admitiu queasidéias religiosas podiam ser utilizadas por "fanáticos" contra a escravidão, e que este sentido político do culto era perigosos, pois foi exatamente "o que se encontrou quando houve a insurreição dos escravos em 1835".

$\mathrm{N}$ o apagar das luzes da primeira metade do século XIX a sombra ameaçadora do levante mal ê ainda era percebida nas ruas do Rio de Janeiro. Este levante que jamais houve, que nunca foi concreto, só nos recei os e apreen sões dos dirigentes do Estado imperial na C orte, fez história. M obilizou esforços, mostrou, mesmo em relances, as entranhas do leviatã negro que colocava em sobressalto moradores e autoridades da maior cidade escrava do país.

Estudos Afro-Asiáticos, Ano 23, ํㅡ2, 2001, p. 31 
M as na década de 1840, os negros minas, longe de serem somente rebeldes incorrigíveis, também partilharam da conjuntura particular que se vivenciava. A alternativa da sedução fora um caminho forjado na impossibilidade de efetivar amplos movimentos armados coletivos dentro da cidade, ou pela vigilância extrema da ordem policial e senhorial, ou mesmo pelas divisões latentes na grande maioria negra da cidade. Entretanto, paradoxalmente, eles também foram aliciados por interesses políticos de grupos das camadas senhoriais.

D esta forma podemos compreender o ingresso de representantes desta nação nos conflitospolíticos que dividiam a elitebranca na década de 1840, como em 1842, quando el es foram arregimentados pelos conservadores na luta contra os insurrectos liberais, que tinham se levantado nas províncias de São Paulo e M inas Gerais (cf. M arinho, 1977 apud M attos, 1986:34). N as duas últimas décadas da monarquia, os comentaristas políticos do tempo observavam espantados, a aliança entreo Partido Conservador eos nagôas, um grupo de capoeira que reunia diversas maltas que dominavam parte da cidade, e participaram ativamente dos conflitos eleitorais e políticos da era da Abolição (cf. Soares, 1998).

Q ual o legado dos minas, equal seu papel na história do protesto negro na cidade? Por mais que pareça que os minas desapare ceram junto com os vel hos africanos remanescentes do tráfico no final do século XIX, temos fortes indícios que eles tiveram papel destacado no imaginário dos trabal hadores negros urbanos da virada do século. No final do século XIX a tradição oral da capoeira citava com insistência os guayamús e os nagôas, dois conglomerados demaltas quedominavam a cidadepelos anos 1870 e $1880.0 \mathrm{~s}$ nagôas se encastelavam principalmente em São José e Santana, onde, décadas atrás, os minas-nagôs tinham seus redutos. As origens da tradição nagôa era derivada de uma raiz escrava e africana, esta última, por sua vez, derivada também dos minas-nagôas e seu êxodo das praias de Salvador até as ruas do Rio de Janeiro.

Assim, estes minas-nagôs, que construíram uma legenda de al tivez erebeldia entre senhores e autoridades, também foram inevitavelmente lidos por grupos subalternos, e estes incorporaram aquilo que era perigoso para uns, como audaz e corajoso para eles. D esta forma, grupos de identidades étnicas diferentes dos minas podem ter introjetado seus valores, e seus signos, sabendo talvez 0 pânico que estes símbolos causavam na mentedos donos do poder. O snagôas dos últimosanos da monarquia - incorporando criouIos, brancos, portugueses - permitiram a continuação da tradi-

Estudos Afro-Asiáticos, Ano 23, no 2, 2001, p. 32 
"Com o Pésobre um Vulcão" : Africanos M inas, I dentidades...

ção, atéa virada do século, quando a Praça 11 era o notório refúgio das memórias nagôs, e berço do samba. ${ }^{67}$

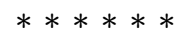

A repressão aos africanos minas na Corte continuaria até 0 fim do século. M uitos deles retornaram à África. O utros tantos se reorganizaram em padrões de moradia própria, ocupações, reconfigurações religiosas e identitárias em várias áreas da cidade. Em 1853, autoridades ainda continuariam invadindo casas de africanos libertos minas e nagôs, alegando conspirações. Africanos libertos enchiam as prisões. Sentimentos de insegurança pública eram reavivadas para justificar intolerâncias e truculências. Tais medidas forçaram o êxodo de muitos deles para África. U m observador estrangeiro diria que os temores quanto às insurreições eram "francamente desmedidos". $\mathrm{Na}$ Bahia, o vice-cônsul inglês ironizava a permanência de tais temores em 1856, posto que bastava a descoberta de "elegantes escritos árabes" para africanos serem perseguidos, encarcerados e banidos (cf. C unha, 1985:80).

Em 1836, um articulista anônimo do Jornal do Commércio defendia, pioneiramente para os padrões brasileiros, a extinção da escravidão, mas o móvel para idéia tão drástica naquele remoto ano não era a elevação do "elemento servil" ou a modernização do I mpério, mas o medo de que o levante malê da Bahia se alastrasse para a C orte, levando todo o I mpério de roldão.

"N ão vimos a Bahia ainda a pouco ameaçada de uma medonha insurreição africana? $\mathrm{N}$ ão sentimosaqui também osmesmos receios? $\mathrm{N}$ ada, nada disto ébastante para desenganar-mosqueestamos continuamentecom 0 pé sobre um vulcão" (D iário do Rio de Janeiro, 1/10/1836:1).

Ao longo do século XIX, os africanos ocidentais, seus descendentes e outros africanos continuaram a redefinir constantemente suas identidades. I dentidades negociadas. A pergunta, considerando não só africanos, mas também crioulos - como aqueles vindos deSalvador posteriormentepelo tráfico interprovincial - eratanto quem é mina, como quem não é. N o Rio de Janeiro urbano, talvez buscando proteção, africanos de vários grupos étnicos ficariam em termos de reconfigurações étnicas - sob um grande "guarda-chuva" mina, como aquele nagô para Salvador. Eram reprimidos, mas também temidos. São várias as imagens e personagens de negros "feiticeiros" minas nos romances do século XIX. Por outro lado, construindo eagenciando identidades, estes africanos minase

Estudos Afro-Asiáticos, Ano 23, ํo 2, 2001, p. 33 
outros controlavam uma parte do mercado de trabal ho com as quitandei ras. Estabeleciam padrões de moradias e sociabilidades.

Também africanos islamizados - os malês - podem ter organizado al gumas comunidades na Corte do Rio de Janeiro. Com medo da repressão, do estigma e protegendo a sua rel igiosidade podem ter ficado invisíveis. Pedaços destas comunidades - reforçada pela continuidade do êxodo de africanos e seus descen dentes de Salvador parao Rio deJ aneiro atéas primeiras décadas do século XX aparecem nos textos de J oão do Rio. Vários cronistas e a memória oral das comunidades negras da chamada "Pequena África", na veIha Praça 11 e também nos bairros Saúde, Santo C risto e G amboa revelam sobre os "tios" e alufás. O utros "misteriosos manuscritos árabes" de africanos islamizados apareceriam (ver Lopes, 1988:68-72; ver, também, M oura, 1994; Vargens\& Lopes, 1982).

V iagens de libertos africanos eseus descendentes para África e o retorno para o B rasil não seriam incomuns. Em várias regiões africanas, as identidades - e posteriormente argumentos diácriticos de "nacionalismos" étnicos - acabariam sendo refeitas com ingredientes das experiências de libertos que retornaram (cf. M atory, 1999; Turner, 1995). Este movimento de realinhamentos identitários de ex-escravos que retornaram para a África nos ajuda a entender as possíveis construções simbólicas e agenciamentos de identidades de africanos nas experiências da escravidão eliberdade no B rasil. Talvez seguindo estas pistas poderemos vislumbrar tradições transétnicas e étnicas de reconfigurações de identidades africanas, crioulas, escravas e livres. O s africanos minas formariam, assim, comunidades intra-atlânticas e transatlânticas. E as margens do Atlântico pareciam querer ficar estreitas.

$\mathrm{N}$ otrassluzindo uma abordagem políticaecultural do tráfico - quenão só refletiam impactos demográficos - já em meados dos anos 80, J oão R eis oferecia reflexões instigantes para pensar as reconfigurações das experiências africanas (e islâmicas) da escravidão urbana de Salvador (cf. Reis, 1986).

Ver os estudos recentes de Slenes (1991-1992, 1995, 1995-1996, 1999).

Ver, entre outros, Cunha (1985), Fry \& Vogt (1996), Reis (1996-1997), Slenes (1991-1992), Silveira (1988). N a bibliografia internacional há várias perspectivas de interpretações sobre a criação de culturas e identidades dos africanos. $H$ á também muita polêmica. Ver, entre outros, A gorsah (1994), Barnes (1992), M intz \& Price (1992 ou 1976), M ullin (1992); Palmié(1995), Stuckey (1987), T hornton (1992) e Vlach (1992).

Estudos Afro-Asiáticos, Ano 23, ํo 2, 2001, p. 34 
"Com o Pésobre um Vulcão" : Africanos M inas, I dentidades...

Ver, além do trabalho clássico deM oura (1972), entreoutros, Reis\& G omes (1996); sobre maroons, ver a revisão das análises em Price (1988-89); ver, ainda, Craton (1982), G aspar (1985) e G enovese (1983).

A inspiração inicial para este texto nasceu com os nossos paperseos debates quando do I Seminário Afro-C arioca, na mesa-redonda intitulada "R eferências M íticas Africanas no Rio deJ aneiro", no dia 6 de outubro de 1999 no Programa de Pós-G raduação em Ciências Sociais na U niversidade Estadual do Rio de Janeiro (UERJ).

AN RJ, IJ 1, maço 859, 0 fícios de Presidentes deProvíncia (RJ), 0 fício do Presidente da Província (RJ) enviado ao M inistro da Justiça, 18.3.1835.

Idem, Códice 334, Carta denúncia anônima, s.d.- GIFI, pacote 5 B 515. Ver, também, AN RJ , O fícios do juiz de paz do primeiro distrito de São J osé ao chefe de polícia da Corte ao ministro da Justiça, 20.2.1836; códice334. Arquivo N acional.

APERJ , 0 fício do juiz de paz da Vila de São J oão do Príncipe ao vice-presidente da província (RJ ), 30.5.1835; fundo PP, coleção 80, eAN RJ , 0 fício do vice-presidente da província (RJ) ao ministro daJ ustiça, 18.5.1835. Ver, também, 0 fício do ministro da justiça ao chefe da Corte, correspondência citada, códice 334, f. 2 v.

AH I, O fício do agente consular do Brasil em Londres ao ministro dos estrangeiros, 2.9.1835. M issões Diplomáticas Brasileiras, ofícios reservados (Inglaterra), códice 217-3-3. Ver, também, ANRJ, Códice 334, Transcrição do ofício citado de 2.9 .1835 , f. 14 v. e $15 \mathrm{v}$.

O s dois casos foram no 3 o D istrito do Sacramento. Ver AN RJ, Ij6-170, "Partes... 28.01.1835".

0 mel hor estudo discutindo as denominações, representações eclassificações étni cas dos africanos ocidentais e minas no Brasil, aparece em O liveira (1997).

Ver Karasch (2000:46-47, tabela I.3) e H olloway (1998:268, apêndice 4), dados também citados em M amigonian (2001:83).

AN RJ , IJ 6 170, 0 fício do Chefede Polícia ao M inistro da ustiça. AN . Em julho de 1831, o Chefe de Polícia denunciou ao $M$ inistro da J ustiça a chegada de nove africanos de Angola que vinham exercer ofício de quitandeiros. D eacordo com o encarregado, eles coabitavam em certas casas com outros africanos libertos e escravos, que serviam também de refúgio para fugidos, e centros de receptação de objetos roubados pelos cativos de seus senhores, e mesmo para sedução e vendas de escravos para fora da cidade. AN RJ, Ij6 - 165, 1831-32, 28. 7.1831.

AN RJ, Ij6 - 170, jan.jul, 1835, O fícios do Chefe de Polícia, respectivamente 4.5.1835, 20.5.1835, 4.6.1835.

Sobrea legislação repressiva do pós-1835 ver R eis op. cit. “O castigo” pp. 254 - 281. E Colleção das Leis do I mpério do Brazil 1835, Rio de Janeiro, Typografia $\mathrm{N}$ acional, 1864. Decreto de 10/06/1835. 0 objetivo era encontrar um carrasco para o município de $V$ assouras, onde novo levante foi abortado. Ele recorreu ao Arsenal de $M$ arinha, a C asa de Correção, ao Aljube, Santa Bárbara, etodas as fortal ezas do Rio. 0 esforço foi em vão. Ver AN RJ, Ij6 - 170, jan./jul. 1835, 29.7.1835.

AN RJ , Ij6 170, jan.jul. 1835, ofício do chefe de polícia ao ministro da justiça.

I dem. "Inclusa vai a tradução que eu dele pude obter, mas não poderá escapar da penetração deV. Exc. a pouca exatidão de uma versão feita por um preto de uma língua quelheéestranha, sendo certo que muitas vezes bastanteme custou a entender o que

Estudos Afro-Asiáticos, Ano 23, ํo 2, 2001, p. 35 
CarlosEugênio Líbano Soares e Flávio G omes

ele dizia. Para entender as primei ras pal avras da tradução é necessário saber que no escrito original supõe ele um poderoso tal ismã contra os sucessos maus da guerra, e quando marcham para a guerra costumam dissolver o papel escrito em água que bebida os faz invulneráveis, ou mesmo cada soldado leva consigo uma linha escrita, e então se persuadem de que as espingardas em vez de fogo despejam sobre eles água. $\mathrm{N}$ a conclusão do escrito aparecem uns poucos de riscos que são as assinaturas. $\mathrm{N}$ otei quequando elelia falava em Alli, quequer dizer D eus, chama, gran de sacerdote, Braima sacerdotee outras palavras, que me parecem assemelhar-se a de que usam os orientais. A vista do contexto da tradução parece-me que aquele escrito contém as deliberações de al gum club queeles formaram, mas ao mesmo tempo as pal avras do princípio e as explicações do preto sobre o uso que lhe costumam dar dá a entender que não é mais do queoração misteriosa na qual supõem os nagôs grandes virtudes. SeV . Exc. tiver a bondade de me enviar outros escritos talvez se consiga avanço maior". Continuamos a pesquisar estes e outros escritos sobre os malês no Rio de Janeiro e suas repercussões.

Em pesquisa em andamento - com fontes inéditas - continuamos a rastrear estes "medos" com relação aos mal ês e african osocidentais no Rio deJ aneiro, entre 1830 e 1880. Sobre escritos malês, ver as interpretações críticas em Reis (1988).

"A pal avra escrita, que os malês utilizavam, tinha grande poder de sedução sobre os africano só familiarizados com a cultura oral. 0 samuletos eram em geral feitos com papéis contendo passagens do Alcorão e rezas fortes. Esses papéis eram cuidadosamentedobrados - operação quetambém tinha sua dimensão mágica - ecolocados numa bolsinha de couro toda costurada" (Reis, 1985).

Era o brigue Triunfo, com 98 escravos: 95 nagôs, 1 crioulo, 1 tapa, 1 pardo e 1 benguela. Todos pertenciam a José de Cerqueira Lima, negociante da Bahia. 0 navio chegou ao Rio em 4 deabril de 1835. AN RJ , Ij6 170, jan.jul,1835, 8.4.1835. Em um ofício ao secretário de visita do posto Eusébio afirma que "a respeito dosescravos vindos da Bahia não permita o desembarque de nenhum, ainda que apresente passaporte, sem apresentar folha corrida.", AN RJ, Ij6 170, jan.jul.1835, 21.3.1835.

"Estes não apresentaram eagora é que depois deestarem com termo de reexportação se apresenta esta fol ha corrida. Se tal precedente passar todos desembarcaram, porque nada é maisfácil do que apresentar uma folha corrida limpa a um escravo que já se acha aqui". O s dois que requerem foram presos no levante de 1835. Ij6 170, jan.jul. 1835, 27.5.1835. Ver também Colleção das deci sões do governo do I mpério do Brazil, [doravanteC D G IB] 1835, Rio de] aneiro, Typographia N acional, 1864, "Limita a certos escravos vindos da Bahia a exigência da folha corrida". D ecisão de 13.4.1835, p. 75.

Sobre as crises regenciais, ostemores de revoltas e motins e o papel da opinião pública na Corte, ver Basile (2000).

AN RJ , Ij6 170, jan.jul.1835, “Partes... 27.5.1835, 10 distrito daC andelária. Foi preso o preto $M$ ina $M$ anoel José $H$ enriques por levantar uma bandeira tricolor em um pau e usar expressões insultantes."

AN RJ, Ij6 170, Partes... 10 D istrito da Freguesia de Santana, 10.4.1835. N a mesma semana são presos o preto $M$ ina liberto $D$ aniel J oão, por crime de injúria, e o preto J osé, de nação M ina, que diz ser forro, por uma bofetada.

Estudos Afro-Asiáticos, Ano 23, ํo 2, 2001, p. 36 
"Com o Pésobre um Vulcão" : Africanos M inas, I dentidades...

"Por quanto a toda presunção e suspeita de quetais pretos são os incitadores e provocadores dos tumultos e comoções a que se tem abalançado os que existem na escravidão". CLIB, 1830, Rio de Janeiro, Typographia Nacional, 1876. Decreto de 14.12.1830. "Estabelece medidas policiais que na província da Bahia se devem tomar em relação aos escravos e pretos forros africanos", p. 96.

AN RJ, Códice 334. Correspondência reservada da polícia, 1833-1846, 17.3.1835. Sobre zungu, ver Soares (1998).

AN RJ, Códice 334. Correspondência reservada da polícia, 1833-1846, 17.3.1835. “Previno V. Exc. que na rua do Valongo próximo ao teatro que ali há me informam que resideum preto, a quem muitos outros se dão o maior respeito, eque ali vão iniciar-se em princípios religiosos e cumpre portanto fazer averiguar pelo juiz de paz respectivo".

"N ão constando ainda resultado algum das diligências que por aviso reservado de 17 do correntese ordenara aosjuizes depaz desta cidade, Engenho Velho eL agoa deFreitas, cumpre que V. M . ordene queenviem a esta Secretaria de Estado com a possível brevidade as informações que Ihe foram recomendadas sobre a conduta dos pretos M inas e libertos e respectivos distritos".

$\mathrm{N}$ o B rasil uma tentativa instigante de mapear comunidades africanas e crioulas em áreas específicas encontra-se com sucesso em R eis (1986). M ais recentemente têm aparecido estudos com pistas sugestivas nesta direção. V er $C$ aron (1997), C hambers (1997), H all (1992) e Goméz (1998).

"Para facilitar a inteligência de al guns manuscritos de pretos M inaseu rogo a V. Exc. quese digne ordenar quena Biblioteca Pública se entregueao francêsJ oséPoix morador na rua dos 0 urives $n-90$ um dicionário quelá existe de árabe para latim em 4 volumes que se restituirá no prazo de um mês".

Códice 334, 22.12.1835, f.17 e 28.12.1835, f.19, "C artas particulares me dizem também que al guns pretos asseveram haver acordo entre el es e os da cidade e de que um tal Andrade pardo forro, que tem casa de quitandas rua do Rosário é um dos agentes do plano que se há de por em execução".

U m estudo defôlego, ecom muitas pistas levantadasa partir defontes, continua sendo Verger (1987).

AN RJ , Ij6 172, jan./jul. 1836, 26.01.1836, ofício do ministro da justiça ao chefe de polícia e deste ao juiz de paz do 10 distrito de São José (AN. Cód. 334, f. 20, 26.1.1836 e 7.1.1836, f. 19. Foram achados também proclamações políticas nas esquinas de rua do Rosário com 0 urives (idem, Ij6 172, jan./jul. 1836, 30.4.1836.

AN RJ , Ij6 171, ago./dez. 1835, Partes...12.11.1835 e.lj6 172, 2.2.1836.

AN RJ, Ij6 172, 2.2.1836 e lj6 172, jan./jul. 1836, 27.6 .1836 e lj6 172, Partes...5.5.1836, 10 distrito de Santa Rita.

Também baseado em Boxer destaca M ott: " 0 que os portugueses e luso-brasileiros chamavam Costa da M ina para os ingleses e batavos incluía os territórios que iam do cabo de Palmas aos $\mathrm{C}$ amarões. Como a maior parte dos negros era exportada pelo porto de Judá, ao serem arrolados seus nomes nos tumbeiros ou quando vendidos no Brasil, no mais das vezes eram identificadostão-somente pelo local de embarque, aumentando ainda mais a enormediversidadecultural e lingüística do étimo ' $M$ ina'. 0 grosso, porém, dos escravos classificados como $M$ ina era, a partir dos primórdios do

Estudos Afro-Asiáticos, Ano 23, ํo 2, 2001, p. 37 
CarlosEugênio Líbano Soareseflávio G omes

século XVIII, do grupo lingüístico I orubá, sendo G êge ou N agô", pp. 103. 0 sescravosafricanos da C osta da $M$ ina eram, de fato, preferidos no comércio negreiro paraa Capitania de M inas G erais. Ver: ZAM ELLA, 1990:185

AN RJ, Códice 80, Correspondência ativa e passiva dos $G$ overnadores do Rio de Janeiro com a Corte (1725-1730), Volume 2, pp.75-6.

Estudos comparativos demográficos sobre a escravidão urbana poderiam ser tentados. Para uma análise recente sobre o tráfico do Sudão C entral de africanos islamizados para o Brasil, ver Lovejoy (2000).

Têm aparecido vários estudos sobre irmandades e as possibilidades de interpretar as redefinições de identidades sociais a partir de festas e práticas mortuárias. Ver, a respeito, Abreu (1998); O liveira (1995); Reis (1997); Rodrigues (1997). M ais uma vez, foi Reis (1995) quem apresentou análises renovadoras sobre a temática. É bom lembrar que as hipóteses instigantes de Silveira (1988) precisam ser testadas

AN RJ, Códice 323, V.7, 03/01/1828. O fício do intendente de polícia ao ministro dosnegócios estrangeiros, f. $88 \mathrm{v} .0$ intendentepedetambém a remessa dos pretosou processará os fâmulos.

AN RJ , Ij6 169, 1834, Partes...10 distrito da C andelária, 24.5.1834.

AN RJ , Ij6 174, 15.2.1837, ofício do subdelegado do 10 distrito de São J osé ao chefe depolícia, AN . H á ainda um grandeprocesso najustiça decrime de sedução deescravos na Freguesia da C andelária (Ij6 174, 8.4.1837).

Antônio M ina, escravo de Francisco de Barros, foi preso por ter sido encontrado na casa de $M$ an uel $F$ rancisco eestar convidando osescravos destes a fugirem. Ver AN RJ, Ij6 185, set./dez, 1837, Partes...10 distrito de Santana, 19.10.1837.

$M$ anoel $M$ ina, escravo do padre $Q$ ueiroz eFaustino $M$ ina, escravo de $M$ anuel detal, foram presos como sedutores de J oaquim Congo, quetambém foi preso. Ver AN RJ, Ij6 185, set./dez. 1837 Partes... 6.12.1837.

AN RJ, I j6 191, jan./maio 1839, 29.12.1838 e 15.1.1839. A documentação sobre passaportes de escravos sendo vendidos para o Rio G rande do Sul é muito vasta no Arquivo Estadual da Bahia.

Caso interessante éo de Antônio M ina, quetentou matar seu senhor com golpes de um compasso, e depois tentou fugir, sendo perseguido pelos outros escravos (cf. AN RJ, lj6 194 " 31.6.1839 e 1806).

Sobre a escravidão urbana no Rio deJ aneiro do século XIX, ver Algranti (1988), Karasch (2000), Silva (1988) e Soares (1988).

Sobre legislação referente a africanos livres, ver Soares (1989:253).

CLIB , 1833, Typographia N acional, 5/12/1833, "D as providências a respeito do tráfico de africanos", p. 545.

AN RJ, Códice 323, V.15, 0 fício enviado ao presidenteda província do Rio deJ aneiro pelo chefe de polícia da corte. 14.9.1839, f.59.

AN RJ, Códice 323, V.15, o fício do chefe de polícia da corte ao chefe de polícia de N iterói, 22/10/1839. 0 preto mina liberto Antônio Barreto foi processado na justiça por sedução e furto de escravos (AN RJ , Ij6 194, jun./dez. 1839, Partes...10 distrito de Santana, 17.9.1839).

AN RJ, Ij6 194, jan.dez. 1839, 06/09/1839. Em fevereiro de 1839 foi a vez de José M ina e Rufino M ina serem deportados para Angola na escuna portuguesa Pallas.

Estudos Afro-Asiáticos, Ano 23, ํo 2, 2001, p. 38 
"Com o Pésobre um Vulcão" : Africanos M inas, I dentidades...

O fício do chefe de polícia ao cônsul brasileiro em Angola. AN RJ , Códice323, V.15, 09/02/1839..

"T enho a honra de passar as mãos deV . Exc. a inclusa representação do Conselheiro José Paulo Figuerôa $\mathrm{N}$ abuco de Araújo, contra um africano de nome F elício, nação mina, cujos serviços em outro tempo foram dados pela provedoria da Comarca, pela razão queo mesmo conselheiro expõevê-senanecessidade da medida por eleproposta de fazê-lo reexportar e por isso peço a $V$. Exc. que se digne autorizar-me para tal fim". Ver AN RJ, Ij6 202, 1844, 0 fício do C hefe de Polícia ao M inistro da Justiça, 24.7.1844.

"[...] vendo-me todos os dias perseguido com cartas em que aquele africano mepedia [para] retira-lo do castigo, em que prometia inteira emenda, etendo atéfeito [o pedido] à minha mulher em carta por mim recebida depois de sua morte, assim como a pessoas que comigo tem divida".

Foi realizada a deportação em 8 de agosto de 1844. Ver AN RJ, Ij6 207, 1844, 12.8.1844.

Sobre a marcas faciais dos minas e outras "nações", ver Prado (s/d:287).

Curiosamente, muitos dos mercadores nativos de escravos na África eram chamados "pombeiros" (Prado, s/d.:287).

AN RJ, Ij6 204, mai./dez. 1845, 12.6.1845, 0 fício do chefe de polícia ao M inistro da Justiça.

AN RJ , Ij6 211, 1848, 21.1.1848, 0 fício do chefe de políciaao M inistro daJ ustiça. AN RJ, Ij6 211, 1848, 25.1.1848: “Em aditamento ao meu ofício tenho a honra de dirigir-me a V. Exc. declarando que o preto africano cuja deportação solicitei tem 0 nome de C esário, sendo a deportação solicitada por J oão J oséPerei ra, quetendo sido seu senhor o forrou, benefício estequenão o sal vou da ingratidão que hojemanifesta o beneficiado".

Antônio M ina, pedreiro, solteiro foi pronunciado em 12 de junho de 1839 por ferimentos graves no seu senhor Joaquim da Silva $\mathrm{N}$ azareth, condenado à morte ea "pagar as custas" [sic]. Foi sentenciado com base na lei de 10 de junho de 1835 (ver AN RJ, Ij6 194, jun.dez. 1839).

Sobre retorno de africanos libertos brasileiros para a África, ver Cunha (1985), Turner (1981) e Verger (1987). Ver, também, sobre "retornados" africanos e ex-escravos cubanos, Sarracino (1991).

AN RJ, Ij6 211, 1848, 06/10/1848. C esário voltou para Angola em 14 de novembro de 1848. Ibidem, 15/11/1848.

Em 1863, a nação mais numerosa entre os africanos escravos presos na $C$ asa de $D$ etenção da C orte era a dos minas (36\%). Livros de Entrada na casa de D eten ção da Corte. Arquivo Público do Estado do Rio de Janeiro.

Para uma reflexão clássica sobre os sentidos políticos da cultura escrava e africana no contexto urbano, ver Reis (1989).

Sobre a Praça 11 e a Freguesia deSantana como refúgio da colônia bai ana no Rio de Janeiro, ver M oura (1994).

Estudos Afro-Asiáticos, Ano 23, oㅡ 2, 2001, p. 39 
Carlos Eugênio Líbano Soares eflávio G omes

\section{Referências Bibliográficas}

ABREU , M artha (1999). 0 Império do D ivino. Festas Reli gi osase C ultura Popular no Rio de Janeiro, 1830-1900. Rio de Janeiro, N ova Fronteira.

AGO RSAH , E. K ofi.(org.) (1994). "M aroon Heritage". Archaelogical Ethnografic and $\mathrm{H}$ istorical Perspectives. U niversity of the W est Indies.

ALGRAN TI, Leila M . (1988). O Feitor Ausente: Estudos deE scravidão U rbana no Rio de Janeiro, 1808-1821. Rio de Janeiro, Vozes.

BAR N ES, Sandra J . (ed.) (1992). Africas O gun O Id W orld and N ew W orld. Indiana U niversity Press.

BASILE, M arcelo O . N . de Campos (2000). Anarquistas, Rusguentose D emagogos: O s Liberais Exaltados ea Formação da Esfera Pública na C orte Imperial (1829-1834). D issertação de M estrado em H istória, Rio de Janeiro, IFCS/UFRJ.

BAST IDE, Roger (1985). AsR eligi ões Africanasno Brasil. Contribuição a uma Soci ol ogia das I nterpenetrações das Ci vilizações. São Paulo, Livraria Pioneira Ed.

_ (1974). AsA méricasN egras: AsC ivilizaçõesA fricanasno N ovo M undo. São Paulo, D ifel/Edusp.

BO XER, C harlesR. (1963). A I dadedo 0 uro do Brasil. São Paulo, C ia. Editora N acional.

CARN EIRO, Edison (1966). 0 Q uilombo dePalmares. (3a ed.). Rio deJ aneiro, Civilização Brasileira.

__ (1964). Ladinos e C rioulos: Estudos sobre o N egro no Brasil. Rio de Janeiro, C ivilização Brasileira.

CARO N, Peter (1997). " 'Of a N ation wich the others do not U nderstand': Bambara Slaves and African Ethnicity in Colonial Lousiana, 1718-1760". Slavery \& Abolition, vol. 18, no 1, pp. 98-121

CARVALH O, M arcus de (1998). Liberdade: Rotinas e Rupturas do Escravismo. Recife, 1822-1850. Recife, Ed. U niversitária.

C H AL H O U B, Sidney (1990). Vi sões da L iberdade: U ma H istória dasÚ ItimasD écadasda Escravidão na C orte. São Paulo, Cia. das Letras.

C H AM BERS, D ouglasB. (1997). "'M y O wn N ation': I gbo Exilesin the D iaspora”. Slavery \& Abolition, vol. 18, no 1, pp. 73-97.

C OST A FILH O , M iguel (1960-61). "Quilombos". Estudos Sociais, números 7, 9, 10 e 11.

CRAT O N, M ichael (1982). Testing the C hains. ResistanceSlavery in theB ritish W est I ndies. Cornell U niversity Press, 1982

C U N H A, M anuela Carneiro da (1985). N egros Estrangei ros: O s Escravos Li ibertos e sua Volta à África. São Paulo, Brasiliense.

D AN T AS, Beatriz Góis (1988). Vovó N agô, Papai Branco. U soseA busos da África no Brasil. São Paulo, Brasiliense.

FLORY, Thomas (1977). "Race and Social Control in Independent Brazil". J ournal of Latin American Studies, vol. 9, no 2, novembro.

FRY, Peter \& VOG T, Carlos. (com a colaboração de Robert Slenes) (1996). Cafundó: A África no Brasil. Linguagem e soci edade. São Paulo, Cia. das Letras.

Estudos Afro-Asiáticos, Ano 23, ํo 2, 2001, p. 40 
GASPAR, D avid Barry (1985). Bondmen \& Rebels. A Study of M aster-Slave Relationsin Antigua with I mplications for $\mathrm{C}$ ol onial British America. The Johns $\mathrm{H}$ opkins U niversity Press.

GEN O VESE, Eugene (1983). D a Rebelião à Revolução: AsRevoltasdeEscravosnas Américas. São Paulo, G lobal.

GO M ES, Flávio dos Santos (1998). "H istória, Protesto e Cultura Política no Brasil Escravista”. In: J. P. Sousa (org.), Escravidão: 0 fícios e Liberdade. Rio de Janeiro, APERJ, pp. 65-97.

GOM ÉZ, M ichael (1998). Exchanging our C ountry M arks. The Transformation of African Identities in the $\mathrm{C}$ ol onial and Antebelum South. The U niversity of $\mathrm{N}$ orth C arolina Press.

H ALL, G wendolyn M idlo (1992). Africans in Colonial Lousiana. The D evelopment of Afro-C reole Culture in the Eighteenth Century. Louisianna, Lousianna StateU niversity Press.

H O LLO W AY, T homas. H . (1998). Polícia no Rio dej anei ro. Repressão e Resistência numa Cidade do Século XIX. Rio de Janeiro, Ed. FGV.

KARASCH , M ary C. (2000). A Vida dosEscravosno Rio deJ aneiro, 1808-1850. São PauIo, Cia. das Letras.

LO PES, N ei (1989). Bantos, M alêsel dentidadeN egra. Rio deJaneiro, Ed. ForenseU niversitária.

LO VEJO Y, Paul E. (2000). "J ihad e Escravidão: As O rigens dos Escravos M ulçumanos da Bahia". Topoi, vol. 1, № 1, pp. 11-44.

M AM IG O N IAN , Beatriz G alloti (2000). “D o que'o Preto M ina' éC apaz: EtniaeR esistência entre Africanos Livres". Afroasia, vol 24, pp. 71-95.

M ARIN H O , José Antônio (1977). H istória do M ovi mento Político de 1842. Belo H orizonte.

M ATO RY, J. Lorand (1999). "J eje: Repensando Nações e Transnacionalismo. M ana, Estudos de Antropologia Social, vol. 5, no 1, abril, pp. 57-80.

M AT T O S, IImar Rohloff de (1986). 0 T empo Saquarema. São Paulo, IN L/H ucitec.

MIN TZ, Sidney W. \& PRICE, Richard (1976). An Anthropological Approach to the Afro-American Past. A Caribbean Perspective. Philadelphia, ISH I.

M O R G AN , Philip D . (1997). "T heC ultural I mplications of the Atlantic Slave: African Regional O rigins, American D estinations and $\mathrm{N}$ ew W orld D evelopments". Slavery \& Abolition, vol. 18, o 1 .

M OTT, Luís (1988). "Acotundá: Raízes Setecentistas do Sincretismo Religioso Afro-Brasileiro". In: L. M ott, Escravi dão, H omossexual idadee D emonologia. São PauIo, İ́ne.

M O U RA, Clóvis (1972). Rebeliões de Senzalas. Ed. Conquista.

M O U RA, Roberto (1994). Tia Ciata ea Pequena África no Rio deJ aneiro. Secretaria M unicipal de Cultura, D GDI, 1994.

M ULLIN , M ichael (1992). Africa in America. Slave Acculturation and Resistance in the America South and the British Caribbean, 1736-1831. University of Illinois Press.

O LIVEIRA, Anderson J. M . de (1995). D evoção e C aridade. I rmandades Religiosas no Rio de Janeiro Imperial (1840-1889). Dissertação de M estrado, N iterói, ICHF/UFF.

Estudos Afro-Asiáticos, Ano 23, oㅡ 2, 2001, p. 41 
CarlosEugênio Líbano Soareseflávio G omes

O LIVEIRA, M aria I nês C ortes de (1997). "Q uem Eram os "N egros da G uiné"? A O rigem dos Africanos na Bahia". Afroasia, vol. 19/20, pp. 3774.

PALM IÉ, Stephan (org.) (1995). Slave Cultures and the Cultures of Slavery. Knoxville, The U niversity of Tennessee Press.

PRAD O , J. F. de Almeida (s/d). TomasEnder: Pintor Austríaco na Corte deD . J oão VI no Rio de Janeiro. São Paulo, Comp. Editora N acional.

PRICE, Richard (1988-89). "Resistance to Slavery in the Americas: M aroons and their Communities". Indian Historical Review, vol. 1-2, no 15.

RAM O S, Arthur (1979). As Culturas N egras no N ovo M undo. (3a ed.). São Paulo, Cia. Ed. Nacional.

(1953). 0 N egro na Civilização Brasil eira. Rio de aneiro, Ed. C asa do Estudante do Brasil.

_ (1942). A Aculturação N egra no Brasil. São Paulo, C ia. Ed. N acional (C oleção B rasiliana).

_ (1935). 0 N egro Brasileiro. Rio de Janeiro, Ed. Civilização Brasileira.

REIS, João J osé (1997). “Identidade e D iversidade Étnica nas I rmandades N egras no Tempo da Escravidão". Tempo, vol. 2, no 3, pp. 7-33.

_ (1995). A M orteéuma Festa. RitosFúnebres eRevolta Popular no Brasil do SéculoXIX. São Paulo, Cia. das Letras.

_ (1989). "O Levantedos M alês: U mal nterpretação Política". In: J. J. Reis\& E. Silva, N egociação e Conflito: Resi stência N egra no Brasil Escravista. São Paulo, Companhia das Letras, pp. 99-122.

_ (1988). "U m Balanço dos Estudos sobreas R evoltasEscravas da Bahia”. In: J . J. Reis, Escravi dão \& Invenção da Liberdade. Estudos sobreo N egro no B rasil l. São Paulo, B rasiliense, pp. 87-140.

_ (1986). Rebelião Escrava no Brasil: A H istória do Levante dos M alês (1835). São PauIo, Brasiliense.

__ \& GO M ES, Flávio dos Santos (1996). “U maH istória da Liberdade”. In: Liberdade por um Fio. História dos Q uilombos no Brasil. São Paulo, Cia. das Letras.

RIBEIRO, G ladys Sabina (1991/1992). "'Pés-de-C humbo' e 'G arrafeiros': Conflitos e Tensões nas Ruas do Rio deJ aneiro no Primeiro Reinado (1822-1831)". Revista Brasileira de H istória, vol. 12, números 23 e 24.

RO D RI GU ES, Claúdia (1997). Lugares dos M ortos na Cidade dos Vivos. Tradições e Transformações Fúnebres no Rio de J aneiro. Prefeitura do Rio deJ aneiro.

RO DRIGUES, Jaime (2000). 0 Infame Comércio. Propostas e Experiências no Final do Tráfico de Africanos para o Brasil (1800-1850). Campinas, Editora da Unicamp/CECULT.

RO D RIG UES, N ina (1977). 0 sA fricanosno Brasil . (5ª ed.). São Paulo, Cia. Ed. N acional.

RU SSEL-W O O D, A. J. R. (1982). The Black M an in Slavery and Freedom in Colonial Brazil. London, M acM illan Press.

SARRACIN O, Rodolfo (1991). "Cuba-Brasil: Os que Voltaram à África". Estudos Afro-Asiáticos, no 20, junho, pp. 85-100.

Estudos Afro-Asiáticos, Ano 23, ํo 2, 2001, p. 42 
"Com o Pésobre um Vulcão" : Africanos M inas, I dentidades...

SILVA, Eduardo (1989). "EntreZumbi ePai J oão: 0 Escravo queN egocia”. In: J. J. Reis \& E. Silva, N egociação e Conflito: Resistência N egra no Brasil Escravista. São Paulo, Companhia das Letras, pp. 13-21.

SILVA, M arileneN ogueira (1988). 0 N egro na Rua: A N ova Faceda Escravidão. São PauIo, $\mathrm{H}$ ucitec.

SILVEIRA, Renato da (1988). "Pragmatismo e M ilagres de Fé no Extremo 0 cidente". In: J. J. R eis, Escravidão \& Invenção da Liberdade. Estudossobreo N egro no B rasil. São Paulo, Brasiliense, pp. 166-197.

SLEN ES, R obert (1999). N a Senzala, uma Flor: "AsEsperanças eas Recordações" na F ormação da Família Escrava. Rio de Janeiro, N ova F ronteira.

_ (1995-1996). "As Provações de um Abraão Africano: A N ascente N ação Brasileira na Viagem Alegórica de Johann M oritz Rugendas". Revista de H istória da Arte e Arqueologia, № 2, pp. 271-536.

(1995). C entral-African W ater Spiritsin Rio deJaneiro: Slavel dentify and Rebellion in Early-N ineteenth Century Brazil. Texto inédito, abril.

_ (1995). Bávaros e Bakongo na "H abitação de N egros": J ohann M oritz Rugen dase a Invenção do Povo Brasileiro, versão de abril de 1995.

_ (1991-1992). "'M alungu, N goma vem!': África Coberta e D escoberta no Brasil”. Revista da U SP, № 12, dez./jan./fev.

SO ARES, C arlosEugênio Líbano (1998). A negregada I nstituição: OsC apoei rasna C orte Imperial, 1850-1890. Rio de Janeiro, Acess.

_ (1998). Zungu: Rumor de M uitas Vozes. Rio de Janeiro, Prêmio Arquivo Estadual.

SO ARES, Luís Carlos (1988). U rban Slavery in N ineteenth C entury Rio de Janeiro. Tese de Ph.D., London, U niversity College.

SO ARES, M ariza de Carval ho (2000). D evotos da Cor. IdentidadeÉtnica, Religi osidadee Escravi dão no Rio de Janeiro, Século XVIII. Rio de Janeiro, Civilização Brasileira.

SO ARES, Sérgio M ota. (org.) (1989). D ocumentação Jurídica sobre o N egro no Brasil, 1800-1888. Salvador, Secretaria de Cultura, DEPAB.

ST U CKEY, Sterling (1987). Slave Culture: N ationalist Theory and the Foundations of Black America. N ova York.

TH ORNT ON, John K. (1992). Africa and Africans in the Making of the Atlantic W orld, 1400-1680. Cambridge, C ambridge U niversity Press.

T U RN ER, J. M ichael (1995). "IdentidadeÉtnica na África O cidental: O C aso Especial dos Afro-Brasileiros no Benim, na N igéria, no Togo e em $G$ ana nos Séculos XIX e XX". Estudos Afro-Asiáticos, no 28, outubro, pp. 85-99.

_ (1981). "Africans, Afro-Brazilians and Europeans, 19th Century Politics on the Benim Gulf". África, Revista do Centro deE studos Africanos daU SP, no 7, pp. 3-31.

VARG EN S, J oão Baptista\& LO PES, N ei (1982). I slamismo \& N egritude. EstudosÁrabes. Rio de J aneiro. Faculdade de Letras U FRJ, 1, 2, sem.

VERGER, Pierre(1987). Fluxo e Refluxo do Tráfico de Escravos entre o $G$ olfo do Benin ea Bahia de Todos os Santos, dos séculos XVII a XIX. São Paulo, Corrupio.

VLACH, J ohn M . (org.) (1992). By the W ork of their $H$ ands. Studies in Afro-American Folklife. Virginia U niversity Press.

Estudos Afro-Asiáticos, Ano 23, no 2, 2001, p. 43 
CarlosEugênio Líbano Soarese Flávio G omes

ZAM ELLA, M afalda (1990). 0 Abastecimento da Capitania das M inas Gerais no Século XVIII. São Paulo, H ucitec/E dusp.

Estudos Afro-Asiáticos, Ano 23, ํo 2, 2001, p. 44 